\title{
Innovative amendments derived from industrial and municipal wastes enhance plant growth and soil functions in potentially toxic elements-polluted environments
}

\author{
Giovanni Garau, ${ }^{1}$ Pier Paolo Roggero, ${ }^{1,2}$ Stefania Diquattro, ${ }^{1}$ Matteo Garau, ${ }^{1}$ \\ Maria Vittoria Pinna, ${ }^{1}$ Paola Castaldi ${ }^{1,2}$ \\ ${ }^{1}$ Dipartimento di Agraria; ${ }^{2}$ Nucleo Ricerca Desertificazione, University of Sassari, Sassari, Italy
}

Highlights

- Water treatment residuals, red muds, municipal solid waste compost and biochar can reduce labile PTE in contaminated soils.

- When used as amendments, WTR, RM, MSWC and BCH improve soil chemical fertility of PTE-polluted soils.

- WTR, RM, MSWC and BCH stimulate soil enzyme activity and heterotrophic bacterial abundance in PTE-polluted soils.

- WTR, RM, MSWC and BCH can be used as strategic amendments to enhance plant growth in environments polluted by PTE.

\begin{abstract}
Potentially toxic elements (PTE), e.g. As, $\mathrm{Sb}, \mathrm{Cd}, \mathrm{Cu}, \mathrm{Pb}, \mathrm{Zn}$, can severely impact soil element cycling, organic matter turnover and soil inhabiting microbiota. Very often this has dramatic consequences for plant growth and yield which are greatly restricted in PTE-contaminated soils. The use of innovative amendments to reduce the labile pool of such soil contaminants, can result as a feasible and sustainable strategy to improve the fertility and functionality of PTE-contaminated soils as well as to exploit these lat-
\end{abstract}

Correspondence: Paola Castaldi, Dipartimento di Agraria, University of Sassari, viale Italia 39, 07100 Sassari, Italy.

Tel.: +39.079229214. E-mail: castaldi@uniss.it

Key words: Water treatment residuals; red muds; municipal solid waste compost; biochar; potentially toxic elements-contaminated soils; plant growth; soil functioning.

Acknowledgements: the financial support of the University of Sassari (Fondo di Ateneo per la Ricerca 2020) and of the Ministero dell'Istruzione, dell'Università e della Ricerca (PRIN 2017 RHIZOBIOREM) are gratefully acknowledged.

Received for publication: 19 November 2020.

Revision received: 23 February 2021.

Accepted for publication: 20 March 2021.

(C) Copyright: the Author(s), 2021

Licensee PAGEPress, Italy

Italian Journal of Agronomy 2021; 16:1777

doi:10.4081/ija.2021.1777

This article is distributed under the terms of the Creative Commons Attribution Noncommercial License (by-nc 4.0) which permits any noncommercial use, distribution, and reproduction in any medium, provided the original author(s) and source are credited. ter from an agronomic point of view. Water treatment residuals (WTR), red muds (RM), organic-based materials originating from the waste cycle, e.g. municipal solid waste compost (MSWC) and biochar $(\mathrm{BCH})$, have emerged in the last decades as promising amendments. In this paper, we report a synthesis of the lessons learned from research carried out in the last 20 years on the use of the above-mentioned innovative amendments for the manipulation of soil fertility and functionality in PTE-contaminated soils. The amendments considered possess physico-chemical properties useful to reduce labile PTE in soil (e.g. alkaline $\mathrm{pH}$, porosity, Fe/Al phases, specific functional groups and ionic composition among the others). In addition, they contain organic and inorganic nutrients which can contribute to improve the soil chemical, microbial and biochemical status. This is often reflected by a higher organic matter content in amended soils and/or an increase of the cation exchange capacity, available $\mathrm{P}$ and total $\mathrm{N}$ and/or dissolved organic C. As a result, soil microbial abundance, in particular heterotrophic fungi and bacteria, and enzyme activities (e.g. dehydrogenase, urease and $\beta$-glucosidase) are commonly enhanced in amended soils, while plant growth can be significantly stimulated. Overall, the obtained results suggest that the studied amendments can be used to reduce PTE bioavailability in polluted soils, improve soil microbial status and functionality, and enhance the productivity of different crops. This can offer a precious opportunity for the productive recovery of PTE-polluted soils.

\section{Introduction}

Soil pollution by potentially toxic elements (PTE, e.g. As, Sb, $\mathrm{Cd}, \mathrm{Cu}, \mathrm{Pb}$ and $\mathrm{Zn}$ ) represents an increasingly urgent problem at global scale. PTE, unlike organic contaminants, are generally immutable, not degradable and persistent in soil (Adriano et al., 2004). In addition, they can be toxic to plants, animals and soil microorganisms when certain threshold levels are exceeded (Abou Jaoude et al., 2019). Unfortunately, this is not uncommon and is often due to industrial and mining activities, waste incinerators, coal and petroleum combustion, spent ammunition, battery facto- 
ries, and misuse of pharmaceuticals and pesticides among the others (Silvetti et al., 2014). For instance, mining and smelting activities usually produce large amounts of tailings and waste rocks, from which PTE present in primary sulphide ores could spread in soil and other environmentally relevant compartments, e.g. surface and groundwater (Wong, 2003; Castaldi et al., 2005; Manzano et al., 2016), thus posing significant environmental and health risks.

The fertility status of PTE-contaminated soils, intended as the soil capacity to support element cycling and promote plant growth, is commonly affected by the presence of PTE above certain thresholds, which interfere with many metabolic pathways impacting plant and microbial physiology (Castaldi et al., 2018; Garau et al., 2014, 2017; Visconti et al., 2018; Garau et al., 2019b). Although such soils cannot be devoted for food or feed production due to their health hazard for humans and animals, they could (and should) be recovered with the aim of limiting the contaminants impact on soil functionality, reduce PTE spread into the environment and promote plant growth. This latter aspect is particularly relevant since the growth of selected plant species in PTE-contaminated soils can be useful for the contaminant stabilization or extraction and such strategies, i.e. phytostabilization and phytoextraction, are currently widely investigated worldwide (e.g. Kumpiene et al., 2014; Garau et al., 2014; Castaldi et al., 2018). Plant growth in PTE-contaminated environments can reduce soil erosion and spread of contaminants, limit PTE mobility and bioavailability through their immobilization in roots, reduce PTE leaching to groundwater and stimulate microbial activity through the release of root exudates (Castaldi et al., 2009b, 2018; Garau et al., 2020). Moreover, the cultivation of plant species with phytoremediation capacities, but also able to produce some income, e.g. bioenergy crops or other no-food crops, can represent an innovative and sustainable approach for the recovery of PTE-contaminated soils which, however, requires a significant improvement of soil fertility, and above all a reduction of the labile (i.e. water-soluble and exchangeable) PTE fractions in soil (Fiorentino et al., 2018).

A wide array of techniques has been proposed to remediate PTE-contaminated soils, most of which consist of very expensive or highly invasive treatments that can only be practiced ex-situ and have a massive impact on the ecosystem (e.g. Mulligan et al., 2001). However, alternative low input (and low cost) and more sustainable approaches have been recently proposed for in-situ remediation of polluted soils. In particular, in the last decades, a great deal of attention has been put on the evaluation of novel and less impacting strategies for gentle remediation of PTE-contaminated soils (Mench et al., 2006; Garau et al., 2014; QuintelaSabarís et al., 2017). Such strategies are mainly based on the insitu immobilization of the contaminants using different amendments (or sorbent materials) often deriving from the municipal or industrial waste cycle, e.g. compost, Fe-rich by-products, biochar etc. (e.g. Castaldi et al., 2005; Garau et al., 2007, 2017; Fellet et al., 2014; Yang et al., 2016; Zhang et al., 2016; Moreno-Barriga et al., 2017). Ideally, these amendments should be able to reduce the concentration of labile and bioavailable PTE by sorption and/or (co)precipitation reactions (Basta and McGowen, 2004; Castaldi et al., 2005; Manzano et al., 2016; Garau et al., 2017; Rocco et al., 2018), and/or by changing the contaminant speciation (Beesley and Marmiroli, 2011), thereby reducing the chemical stress imposed on plants and soil microorganisms. Importantly, the contribution of such amendments for the recovery of PTE-contaminated soils should not be limited to reduce labile PTE, as this could not be enough to promote plant growth and achieve suitable yields. For instance, adding 3\% (w/w) hematite [an iron(III) oxide; $\mathrm{Fe}_{2} \mathrm{O}_{3}$ ] significantly reduced labile As in a contaminated mining soil but did not improve Phaseolus vulgaris growth which was similar to that achieved in the contaminated untreated soil (Garau et al., 2014). This was explained by the authors with bean sensitivity to $\mathrm{Fe}_{2} \mathrm{O}_{3}$ but could be due also to $\mathrm{P}$ deficiency since Fe-oxides have a great affinity for phosphates (Antelo et al., 2005; Luengo et al., 2006). It is therefore of utmost importance that amendments used for soil remediation are able to improve soil physico-chemical and biological attributes (e.g. $\mathrm{pH}$, cation exchange capacity, nutrient supply, microbial abundance, diversity and functionality) other than just reducing labile PTE. The combined presence of such characteristics in each amendment can significantly contribute to plant growth in PTE-contaminated soils and can be the key to achieve economically relevant yields in such environments.

In this review paper, the suitability of several amendments, mainly deriving from the municipal or industrial waste cycle, for the recovery of PTE-contaminated soils and the promotion of plant growth in such environments, will be discussed from a chemical, biochemical, and agronomic viewpoint. In particular, the main physico-chemical features of selected strategic amendments such as municipal solid waste compost (MSWC), red muds (RM), water treatment residuals (WTR) and biochar $(\mathrm{BCH})$ will be presented together with their PTE-adsorption capacities. The amendments impact on the fertility, biochemical and microbial characteristics of different PTE-contaminated soils will be also discussed. Finally, the amendments potential to influence plant growth and PTE uptake in contaminated soils will be also reported with emphasis to selected grass and legume species (e.g. Lupinus albus, Pisum sativum, Phaseolus vulgaris, Triticum vulgare) as well as to some multipurpose crops (e.g. Helichrysum italicum, Cynara cardunculus, Phragmites australis and Arundo donax).

\section{Origin and physico-chemical features of municipal solid waste compost, red muds, water treatment residuals and biochar}

The municipal and industrial waste cycle produces large amounts of by-products which almost always constitute an environmental issue with relevant economic implications. For instance, in 2019, RM deriving from the Alumina industry in Portovesme (Sardinia, Italy) amounted to approx. $20 \mathrm{Mm}^{3}$ distributed over 160 ha located in front of the coast line at $26 \mathrm{~m}$ asl (Mombelli et al., 2019). Drinking water treatment plants also produce continuously large amounts of sludges, i.e. WTR, which involves considerable transport and landfill costs. In 2016, WTR production by a typical water treatment plant was estimated of 100,000 $\mathrm{t}_{\text {year }}{ }^{-1}$ while more than 10,000 t were produced daily on a global scale (Ahmad et al., 2016). The same can be said for compost, or more recently for biochar resulting from the transformation of organic (e.g. food and green) wastes and whose volumes are constantly increasing due to growing world population. At present, these kinds of materials or by-products mainly represent a problem (and only marginally a resource) while they could be effectively used as amendments for the reclamation of contaminated soils. In particular, MSWC, RM, WTR, and $\mathrm{BCH}$, given their physico-chemical features, could be used as strategic amendments in PTE-contaminated soils, thus improving the fertility of contaminated soils and enhancing plant growth and productivity. 


\section{Municipal solid waste compost}

Compost is the by-product of a controlled bio-oxidation process carried out by diverse microbial populations under aerobic conditions. The composting process basically involves the degradation of organic residues of plant and animal origin, or green and food waste as in the case of MSWC, and their conversion into a stabilized product. The end product is rich in humus and plant nutrients whereas carbon dioxide, water, and heat are common byproducts (Castaldi et al., 2009a). The main properties of MSWC are reported in Table 1. Total organic carbon in MSWC is higher than $20 \%$ with stabilized organic matter, that is humic and fulvic acids, representing approximately $50 \%$ of total organic carbon (TOC; Table 1 ). The $\mathrm{C} / \mathrm{N}$ ratio is commonly $\sim 10$. Stable compost generally shows high cation exchange capacity $\left(\mathrm{CEC}>70 \mathrm{cmol}_{(+)}\right.$ $\left.\mathrm{kg}^{-1}\right)$ and dissolved organic carbon (DOC) content (0.6-1.9 $\mathrm{g} \mathrm{kg}^{-}$ ${ }^{1}$ ). Quantitative assessments of element composition indicate that $\mathrm{Fe}, \mathrm{Mg}$ and, above all, $\mathrm{Ca}$ are abundant in MSWC (Table 1), while the concentrations of $\mathrm{Pb}, \mathrm{Zn}, \mathrm{Cd}$, and $\mathrm{Cu}$ can vary depending on the starting waste and should not exceed the maximum level allowed for organic amendments by the Italian law (Regulation (EU) 2019/1009).

Because of these physico-chemical properties, MSWC could be a strategic resource for the improvement of soil functionality and plant growth in PTE-contaminated soils (Castaldi et al., 2005, 2018; Garau et al., 2020). Moreover, humic substances of MSWC can immobilize PTE forming complexes of different strengths and reducing their mobility and bioavailability in soil (Paradelo and Barral, 2012; Silvetti et al., 2017). This is due to a high surface charge density of humic substances and to their functional groups such as carboxyl, phenolic, hydroxyl, carbonyl, and sulfhydryl which are particularly active in the formation of metal-organic complexes. However, the role of MSWC in the mobility of certain anionic contaminants such as $\mathrm{Sb}(\mathrm{V})\left[\mathrm{Sb}(\mathrm{OH})_{6}{ }^{-}\right]$or $\mathrm{As}(\mathrm{V})$ $\left[\mathrm{H}_{2} \mathrm{AsO}_{4^{-}}, \mathrm{HAsO}_{4}{ }^{2-}\right]$ is currently under debate (Udovic and McBride, 2012; Sundman et al., 2015; Manzano et al., 2016; Diquattro et al., 2018) and will be further discussed below.

\section{Red muds}

Red muds, a by-product of the Alumina industry, is the alkaline material ( $\mathrm{pH} 10-13)$ which remains after the digestion of bauxite with caustic soda during alumina extraction in the Bayer process (Garau et al., 2007, 2011; Lee et al., 2011; Lyu et al., 2021). Depending on the quality of bauxite, the amount of RM generated varies between 55 and $65 \%$ of the bauxite processed. Roughly 1.0$1.5 \mathrm{Mg}$ of $\mathrm{RM}$ are produced for each $\mathrm{Mg}$ of alumina and consequently millions of $\mathrm{Mg}$ of caustic RM are generated world-wide (e.g. about 200 million Mg in 2018; Lyu et al., 2021). The main chemical characteristics of RM are reported in Table 1. As mentioned before, RM generally show a low specific surface $\left(<20 \mathrm{~m}^{2}\right.$ $\mathrm{g}^{-1}$; Castaldi et al., 2011) and contain substantial concentrations of $\mathrm{Na}\left(\right.$ e.g. $>500 \mathrm{mg} \mathrm{kg}^{-1}$ in Garau et al., 2011) which can have obvious negative consequences on plant growth, especially for sensitive species. Most of RM are generally made of a mixture of $\mathrm{Fe}$ and $\mathrm{Al}$ (hydr)oxides such as hematite $\left(\mathrm{Fe}_{2} \mathrm{O}_{3}\right)$, boehmite $[\mathrm{AlO}(\mathrm{OH})]$ and gibbsite $\left[\mathrm{Al}(\mathrm{OH})_{3}\right]$, while different tectosilicatelike compounds such as cancrinite $\left[\mathrm{Na}_{6} \mathrm{Ca}_{2} \mathrm{Al}_{6} \mathrm{Si}_{6} \mathrm{O}_{24}\left(\mathrm{CO}_{3}\right)_{2}\right]$ and sodalite $\left[\mathrm{Na}_{8} \mathrm{Al}_{6} \mathrm{Si}_{6} \mathrm{O}_{24} \mathrm{Cl}_{2}\right]$ can be also abundantly present (Castaldi et al., 2011; Evans, 2016). As such, RM are not expected to provide soil with mineral elements of plant significance, or to significantly increase soil organic matter, this could imply a limit-

Table 1. Chemical characteristics of municipal solid waste compost, red muds, water treatment residuals and biochar.

\begin{tabular}{|c|c|c|c|c|}
\hline Chemical parameters & MSWC & RM & WTR & $\mathrm{BCH}$ \\
\hline $\mathrm{pH}_{\mathrm{H} 2 \mathrm{O}}$ & $7.93-8.86$ & $11.0-11.5$ & $6.45-7.88$ & $8.85-9.30$ \\
\hline $\mathrm{EC}\left(\mathrm{mS} \cdot \mathrm{cm}^{-1}\right)$ & $1.24-15.58$ & $2.15-8.70$ & $3.01-5.69$ & $9.91-11.67$ \\
\hline Ashes (\%) & $42.05-46.42$ & $98.45-98.74$ & $42.05-56.67$ & 31.86 \\
\hline Total organic carbon (TOC, \%) & $24.53-27.34$ & $0.30-0.35$ & $8.42-14.15$ & 41.52-61.32 \\
\hline Dissolved organic Carbon (DOC, $\mathrm{g} \mathrm{kg}^{-1}$ ) & $0.603-1.944$ & - & 0.101 & $0.02-2317$ \\
\hline Cation Exchange Capacity $\left(\mathrm{cmol}(+) \mathrm{kg}^{-1}\right)$ & $77.75-93.30$ & $9.8-10.7$ & 75.02 & 18.81-105.1 \\
\hline Total phosphorus ( $\left.\mathrm{g} \mathrm{kg}^{-1}\right)$ & $7.14-13.06$ & - & $0.68-0.89$ & - \\
\hline Total nitrogen (N, \%) & $1.80-2.80$ & - & $0.80-0.87$ & $0.30-1.34$ \\
\hline Humic + fulvic acids (HA+FA, \%) & $12.19-15.34$ & - & - & - \\
\hline \multicolumn{5}{|l|}{ Total PTE concentration ( $\mathrm{mg} \mathrm{kg}^{-1}$ ) } \\
\hline $\mathrm{Pb}$ & n.d. -85.00 & $13.4-48.5$ & 12.17-21.17 & n.d. -0.34 \\
\hline $\mathrm{Zn}$ & 26.91-209 & 0.025 .2 & 246.03-121.86 & n.d.-2.50 \\
\hline $\mathrm{Cd}$ & n.d.- 0.42 & n.d.-1.46 & $0.24-0.30$ & n.d. \\
\hline $\mathrm{Cu}$ & n.d.-19.24 & $0.01-23.9$ & $29.0-51.48$ & 207.1 \\
\hline As & n.d. & n.d. & - & n.d. \\
\hline $\mathrm{Sb}$ & n.d. & n.d. & - & n.d. \\
\hline $\mathrm{Fe}$ & $5494-22,929$ & 3035 & $17,437-245,480$ & 524.8 \\
\hline $\mathrm{Mn}$ & $140.5-594.73$ & - & $31,636-8645$ & 358.1 \\
\hline $\mathrm{Na}$ & $993.3-2534$ & 517 & $32.15-156.46$ & - \\
\hline K & $1709-2780$ & - & $99.48-3827$ & - \\
\hline $\mathrm{Mg}$ & $4504-5403$ & - & 69.54-2032 & - \\
\hline $\mathrm{Ca}$ & $63,444-80113$ & 104 & $89.34-11,027$ & - \\
\hline
\end{tabular}

*Data from: Castaldi et al., 2005, 2011, 2014, 2015; Garau et al., 2007, 2011, 2014, 2017; Manzano et al., 2016, 2020; Silvetti et al., 2017; Diquattro et al., 2018; Abou Jaoude et al., 2019, 2020; Garau et al., 2019b. n.d., not detected; MSWC, municipal solid waste compost; RM, red muds; WTR, water treatment residuals; BCH, biochar. 
ed influence on plant growth. However, the high alkalinity of this material can be important to improve element cycling (e.g. N-fixation) and soil organic matter turnover in acidic soils, where microbial communities and their functioning are commonly affected by low $\mathrm{pH}$ values (Garau et al., 2007). Importantly, this also applies to acidic PTE-contaminated soils and can have obvious positive implications for plant growth (Castaldi et al., 2009b). Moreover, RM addition to these latter soils can significantly contribute to contaminant fixation due its alkaline $\mathrm{pH}$ (PTE in cationic form such as $\mathrm{Pb}, \mathrm{Cu}$ and $\mathrm{Zn}$ tend to precipitate as insoluble oxides or hydroxides as the $\mathrm{pH}$ raises) and adsorptive capacity (Fe and $\mathrm{Al}$ (hydr)oxides and tectosilicate-like compounds within RM can be very effective at PTE immobilization; Summer et al., 1996; Apak et al., 1998; Phillips, 1998; Gupta and Sharma, 2002; Santona et al., 2006).

\section{Water treatment residuals}

WTR are the sludges deriving from the purification of the raw water for civil uses with different coagulants which are added to (co)precipitate particulate organic matter and/or dissolved chemicals from the raw water. The most common coagulants used are aluminium $\left(\mathrm{Al}_{2}\left(\mathrm{SO}_{4}\right)_{3} \cdot 18 \mathrm{H}_{2} \mathrm{O}\right)$, ferric (e.g., $\left.\mathrm{FeCl}_{3} \cdot 6 \mathrm{H}_{2} \mathrm{O}\right)$ and ferrous (e.g., $\mathrm{FeCl}_{2}, \mathrm{FeSO}_{4} \cdot 7 \mathrm{H}_{2} \mathrm{O}$ ) salts, which can greatly influence the final WTR composition (Ippolito et al., 2011). Although this latter can vary, such amorphous material is characterized by the presence of organic matter (particulate and dissolved) and mineral elements (Castaldi et al., 2015; Ippolito et al., 2011; Ahmad et al., 2016). The chemical properties of WTR (Table 1) makes this sludge a potentially suitable amendment to improve the fertility of degraded soils, such as PTE-contaminated ones, and enhance plant growth therein. Importantly, WTR are characterised by a porous and amorphous nature, mostly made of $\mathrm{Al}$ or $\mathrm{Fe}$ (oxy)hydroxides [e.g. $\mathrm{Al}(\mathrm{OH})_{3}$ or $\left.\mathrm{Fe}(\mathrm{OH})_{3}\right]$ (depending on the coagulant added), which confer to this material a great effectiveness in PTE adsorption (Santona et al., 2006; Castaldi et al., 2014, 2015, 2018).

\section{Biochar}

Biochar, i.e. the carbonaceous material originated from the pyrolysis of organic wastes in low-oxygen conditions and variable temperature $\left(200-900^{\circ} \mathrm{C}\right)$, is emerging as potentially effective and environmental-friendly amendment for the recovery of PTE-polluted soils (Mehmood et al., 2018; Lebrun et al., 2019), which also implies the promotion of plant growth in such environments (e.g. Ibrahim et al., 2017; Yousaf et al., 2018). BCH is an alkaline sorbent (Table 1) rich in aromatic carbon that confers a substantial chemical and biological stability to the material, it is also characterized by a porous structure encompassing micro, meso and macro pores (Jindo et al., 2014; Xu et al., 2017). The pyrolysis conditions (i.e. temperature and time) are key factors influencing the physical and chemical properties of biochar, e.g. high temperatures $\left(>500^{\circ} \mathrm{C}\right)$ decrease biochar acidity and increase its specific surface area (Jindo et al., 2014; Xu et al., 2017). BCH contains high total organic carbon (generally $>40 \% \mathrm{w} / \mathrm{w}$ ), extractable $\mathrm{P}$ and $\mathrm{Ca}$, while its CEC, total $\mathrm{N}$ and DOC are lower than other organic amendments such as compost (Table 1). Like MSWC, PTE concentration in $\mathrm{BCH}$ can vary depending on the organic waste of origin and, for its use in agricultural soils, it should not exceed the thresholds imposed by the national norms for amendments and fertilisers (Regulation (EU) 2019/1009).

$\mathrm{BCH}$ physico-chemical characteristics (e.g. alkalinity, high extractable $\mathrm{P}$ and $\mathrm{Ca}$ content) make it a suitable amendment for the enhancement of soil fertility (Zhang et al., 2013; Li et al., 2017), as well as microbial abundance and activity (Gómez et al., 2014; $\mathrm{Xu}$ et al., 2017). Moreover, growing evidence suggest that $\mathrm{BCH}$ can have a significant role in decreasing the mobility of PTE (Fang et al., 2016; Abou Jaoude et al., 2020; Manzano et al., 2020). Overall, this is due to its microporous structure and high surface area as well as to the presence of different functional groups (e.g. $-\mathrm{COOH}, \mathrm{Ar}-\mathrm{OH},-\mathrm{NH}_{2}$ ) able to retain positively and negatively charged PTE species (Xu et al., 2013; Bandara et al., 2016; Mehmood et al., 2018; Qiao et al., 2018). In addition, BCH alkalinity can contribute to limit the mobility and bioavailability of selected PTE such as metal cations, through the formation of insoluble Me oxides or hydroxides.

\section{Influence of municipal solid waste compost, red muds, water treatment residuals and biochar on soil physico-chemical characteristics}

As discussed earlier, MSWC, RM, WTR and BCH present interesting physico-chemical features which make them promising candidates for improving soil fertility in PTE-contaminated soils. However, the peculiarity of each contaminated soil (i.e. specific origin, texture, $\mathrm{pH}$, point of zero charge, organic matter content, relative and absolute PTE abundance and speciation, and so on) requires case by case experimental evidence before proceeding with large-scale interventions. This point should not be overlooked, and the lesson to learn from previous research is that such amendments are not effective in all soils. For instance, adding RM to an acidic soil ( $\mathrm{pH} 4.2$ ) contaminated with $\mathrm{Pb}, \mathrm{Cd}$ and $\mathrm{Zn}$ significantly increased plant growth (Castaldi et al., 2009b), while the same RM had opposite results when added to a neutral soil ( $\mathrm{pH}$ 6.8) contaminated with $\mathrm{As}, \mathrm{Pb}, \mathrm{Cd}$, and $\mathrm{Zn}$ (Garau et al., 2014).

\section{Municipal solid waste compost}

Compost addition (in the $2-10 \% \mathrm{w} / \mathrm{w}$ range) to PTE-polluted (and unpolluted) soils commonly results in a $\mathrm{pH}$ increase between $\sim 1$ and 4 units (e.g. Castaldi et al., 2005; Tandy et al., 2009; Huang et al., 2016; Manzano et al., 2016; Garau et al., 2019b; Table 2). For instance, a pH increase from 3.9 up to 7.0 was observed by Alvarenga et al. (2008) in a PTE-polluted mining soil after amendment with $100 \mathrm{Mg} \mathrm{ha}^{-1} \mathrm{MSWC}$. This can be particularly helpful in (sub)acidic-polluted soils where MSWC addition can reduce the solubility of certain PTE (e.g. metal cations) and limit Al toxicity (e.g. Castaldi et al., 2005; Alvarenga et al., 2008; Tandy et al., 2009; Manzano et al., 2016; Palansooriya et al., 2020). In the long term, such $\mathrm{pH}$ increase (which is in general proportional to the rate of compost applied; see also Alvarenga et al., 2008) is also expected to improve soil organic matter turnover and element cycling which will contribute to providing a better environment for plant growth. Compost addition, especially at a high rate (e.g. $4 \% \mathrm{w} / \mathrm{w})$, can also improve other fertility attributes such as CEC, TOC, available $\mathrm{P}$ and total $\mathrm{N}$ content (e.g. Castaldi et al., 2005; Diacono and Montemurro, 2010; Tandy et al., 2009; Manzano et al., 2016; Garau et al., 2019b; Siedt et al., 2021; Table 2). For instance, it has been shown that soil organic carbon and humic content can increase up to 30 and $2 \%$ respectively after repeated MSWC amendment (Diacono and Montemurro, 2010; Siedt et al., 2021). Moreover, remarkable DOC increases were observed in MSWCamended soils and this was positively correlated with increased microbial abundance and activity (Manzano et al., 2016; Abou Jaoude et al., 2019; Garau et al., 2019b). For instance, DOC 
increased from 42 to 100 and from 74 to $140 \mathrm{mg} \mathrm{kg}^{-1}$ soil respectively after $3 \%(\mathrm{w} / \mathrm{w})$ addition of MSWC to two Lebanese PTEpolluted soils (Abou Jaoude et al., 2019). However, the role of DOC in PTE-contaminated soils is rather controversial as, in some instances, it appeared positively correlated with increased PTE solubility (Manzano et al., 2016; Palansooriya et al., 2020).

\section{Red muds}

As anticipated, the addition of RM to polluted soils resulted in significant $\mathrm{pH}$ increases, but also higher electrical conductivity (EC) and exchangeable Na (Table 3) (Lombi et al., 2004; Garau et al., 2007, 2011, 2014; Nejad et al., 2021). For instance, adding 2\% (w/w) RM to a PTE-polluted mining soil raised the $\mathrm{pH}$ from approx. 6.7 up to 8.0 and EC from approx. 100 up to $120 \mu \mathrm{S} \mathrm{cm}^{-1}$ (Nejad et al., 2021). Interestingly, a remarkable loss of stabilised soil organic carbon ( $40 \%$ ), and a significant increase of water-soluble C, N, P, phenols and carbohydrates was observed in a PTEcontaminated soil after 2 years since RM addition at $4 \%(\mathrm{w} / \mathrm{w})$ rate (Garau et al., 2011). This was attributed to RM alkalinity and high $\mathrm{Na}$ content which likely promoted the dispersion of soil organic matter (SOM) and the consequent release of water-soluble compounds. Unfortunately, the relevance of such phenomenon in terms of plant growth was not reported even if the size and activity of microbial populations in RM-treated soil were significantly increased compared to the untreated polluted soil (Garau et al., 2011). This, in turn, could have led to an enhanced/accelerated SOM degradation as a result of co-metabolism and higher enzyme activity (Blagodatskaya and Kuzyakov, 2008; Garau et al., 2011, 2014). Finally, $\mathrm{Fe}$ and $\mathrm{Al}$ (oxy)hydroxides, abundant components of RM ( up to 60\%; Castaldi et al., 2011), have a great affinity for phosphates $\left(\mathrm{H}_{2} \mathrm{PO}_{4}^{-}\right.$and $\left.\mathrm{HPO}_{4}{ }^{2-}\right)$ other than toxic arsenates $\left(\mathrm{H}_{2} \mathrm{AsO}_{4}{ }^{-}\right.$and $\left.\mathrm{HAsO}_{4}{ }^{2-}\right)$. Taneez and Hurel (2019) in their review reported arsenate and phosphate removal capacities by RM in the $0.38-68$ and $0.58-161 \mathrm{mg} \mathrm{g}^{-1}$ range, respectively. This means that $\mathrm{P}$ deficiencies can be observed in RM-amended soils as highlighted by Castaldi et al. (2009b).

\section{Water treatment residuals}

WTR added to polluted soils generally caused moderate increases in soil $\mathrm{pH}, \mathrm{TOC}$ and $\mathrm{CEC}$, and in some cases also the DOC content increased (Table 2) (Garau et al., 2014, 2017; Manzano et al., 2016; Zhao et al., 2018). For instance, Zhao et al. (2016) observed a $63.9 \%$ increase of CEC after adding $100 \mathrm{~g} \mathrm{WTR}$ $\mathrm{kg}^{-1}$ soil. An increase of point of zero charge $\left(\mathrm{pH}_{\mathrm{PZC}}\right)$ was reported by Garau et al. (2014) in a polluted soil after amendment with $4 \%$ (w/w) Fe-rich WTR, e.g. from 6.7 to 8.6. This was relevant for the immobilisation of anionic PTE such as arsenates but could be also useful to increase the soil capacity to retain useful anions (e.g. phosphates). The increase of soil $\mathrm{pH}_{\mathrm{PZC}}$ after WTR addition, also reported by Manzano et al. (2016) (Table 2), can be explained with the high content of $\mathrm{Fe}$ or $\mathrm{Al}$ (oxy)hydroxides [e.g. $\sim 25 \%$ of total $\mathrm{Fe}$ was present in the WTR investigated by Garau et al. (2014)] which are characterised by $\mathrm{pH}_{\mathrm{PZC}}$ values between $~ 7.0-9.0$ (Kosmulski, 2016). However, this finding cannot be generalized as decreases of $\mathrm{pH}_{\mathrm{PZC}}$ were also reported after WTR addition (Table 2).

Table 3. Influence of red muds, added at $4 \%(w / w)$ rate, on selected chemical characteristics of an acidic potentially toxic elements -contaminated soil.

\begin{tabular}{lcc} 
& Untreated soil & RM-soil \\
$\mathrm{pH}_{\text {H2O }}$ & 6.84 & 8.80 \\
Electric conductivity $\left(\mu \mathrm{S} \mathrm{cm}^{-1}\right)$ & 214.5 & 351.5 \\
\hline Total organic C $\left(\mathrm{g} \mathrm{kg}^{-1}\right)$ & 39.34 & 33.03 \\
Water soluble C $\left(\mathrm{g} \mathrm{kg}^{-1} \mathrm{~d} . \mathrm{m}.\right)$ & 3.40 & 7.08 \\
\hline Total N $\left(\mathrm{g} \mathrm{kg}^{-1}\right)$ & 1.53 & 1.22 \\
Point of zero charge (PZC) & 6.68 & 4.71 \\
\hline Total PTE concentration ( $\mathrm{mg}^{\left.-\mathrm{kg}^{-1}\right)}$ & & \\
$\mathrm{As}$ & 2105.28 & 2020.38 \\
$\mathrm{Cd}$ & 18.04 & 17.38 \\
\hline $\mathrm{Cu}$ & 264.78 & 243.86 \\
$\mathrm{~Pb}$ & 714.05 & 685.46 \\
\hline $\mathrm{Zn}$ & 522.53 & 518.93 \\
\hline
\end{tabular}

Data from Garau et al. (2014). RM, red muds; PTE, potentially toxic elements.

Table 2. Influence of municipal solid waste compost and water treatment residuals, added at 4 and $2 \%$ (w/w) rate respectively, on selected chemical characteristics of different potentially toxic elements-contaminated soils (S1, S2 and S3).

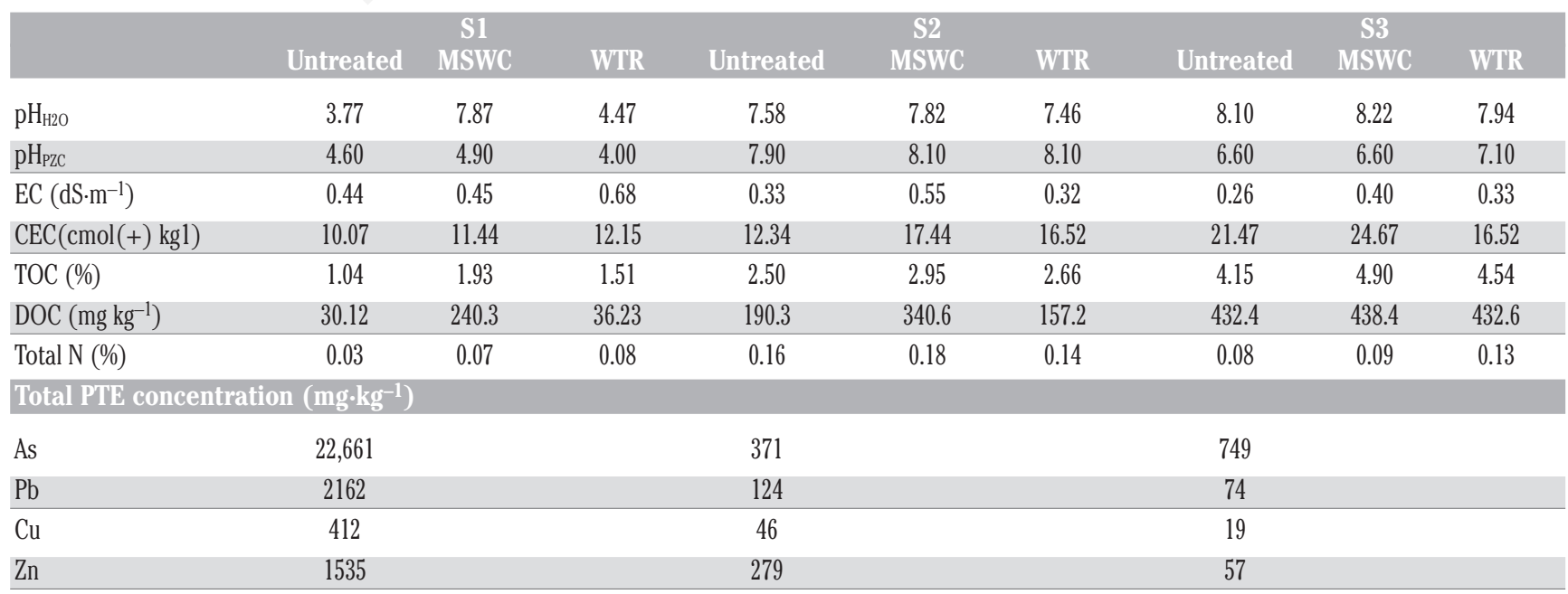

Data from Manzano et al. (2016). MSWC, municipal solid waste compost; WTR, water treatment residuals; PTE, potentially toxic elements. 


\section{Biochar}

Similarly to the other amendments, BCH addition to PTE-polluted soils generally resulted in a $\mathrm{pH}$ increase which was due to its alkaline nature (i.e. $\mathrm{BCH} \mathrm{pH}$ is mostly in the 8.9-9.3 range; Table 1). Importantly, also $\mathrm{CEC}$ and $\mathrm{OM}$ content generally increased after BCH amendment (Table 4) (Abou Jaoude et al., 2019; Lebrun et al., 2019; Manzano et al., 2020). Depending on the biochar type, DOC content significantly increased in treated soils (Abou Jaoude et al., 2020), while it decreased in others (Table 4; Manzano et al., 2020). This can be explained with the different DOC content of the $\mathrm{BCH}$ added, which in turn depends on the organic biomass and pyrolysis conditions, as well as by a certain adsorption capacity of $\mathrm{BCH}$. For instance, the BCH used by Abou Jaoude et al. (2020) was obtained at low temperature $\left(\right.$ i.e. $400^{\circ} \mathrm{C}$ ) by MSW, and had a DOC content of $2300 \mathrm{mg} \mathrm{kg}^{-1}$, while that of Manzano et al. (2020) was obtained at high temperature (i.e. $800^{\circ} \mathrm{C}$ ) by softwood and contained approx. $0.02 \mathrm{mg} \mathrm{kg}^{-1}$ DOC. Such a low DOC content suggested that almost all biochar's $\mathrm{C}$ was recalcitrant and insoluble. Importantly, when this latter $\mathrm{BCH}$ was added to two different PTE-polluted soils, the DOC content significantly decreased indicating that $\mathrm{BCH}$ actively adsorbed dissolved organic compounds in soil (Table 4; Manzano et al., 2020), as also reported by other authors (e.g. Lin et al., 2012; Eykelbosh et al., 2015). As anticipated, this can have relevant consequences on the size and activity of soil microbial populations and indirectly on plant-growth. Different researchers reported high amounts of available $\mathrm{P}$ and exchangeable $\mathrm{Ca}$ in $\mathrm{BCH}$ that are supplied to the amended soils, mostly resulting in significant increases (e.g. Glaser and Lehr,
2019; Jien and Wang, 2013). For instance, Glaser and Lehr (2019) reported that $\mathrm{BCH}$ increased $\mathrm{P}$ availability in agricultural soil by a factor of 4.6 irrespective of the feedstock used. Our experimental evidence supports such conclusions, e.g. available P significantly increased from 31 to 40 and from 37 to $56 \mathrm{mg} \mathrm{kg}^{-1}$ in two PTEcontaminated soils treated with $5 \%(\mathrm{w} / \mathrm{w})$ softwood BCH (Table 4; Manzano et al., 2020). Significant increases in exchangeable $\mathrm{Ca}$ were also reported in the same study.

Generally, the addition of MSWC, RM, WTR and BCH did not cause a significant change in the total concentration of soil PTE (Castaldi et al., 2005; Garau et al., 2007, 2011, 2014, 2017; Manzano et al., 2016, 2020; Abou Jaoude et al., 2019, 2020; Garau et al., 2019b). This is a fundamental prerequisite for the use of these amendments in contaminated (but also uncontaminated) soils and should be always verified before proceeding with any other investigation.

\section{Influence of municipal solid waste compost, red muds, water treatment residuals and biochar on labile potentially toxic elements in contaminated soils}

The aim of in-situ immobilization of PTE is to reduce their labile fractions, i.e. water-soluble and potentially bioavailable ones (e.g. easily exchangeable PTE), which impact most soil (micro)biota (including plants) and soil biochemical functioning.

Table 4. Influence of a softwood-derived biochar on physico-chemical characteristics of the different potentially toxic elements-polluted soils.

\begin{tabular}{|c|c|c|c|c|}
\hline \multirow[t]{2}{*}{ Chemical analyses } & \multicolumn{2}{|c|}{ Soil 1} & \multicolumn{2}{|c|}{ Soil 2} \\
\hline & Untreated & BCH-soil & Untreated & BCH-soil \\
\hline $\mathrm{pH}_{\mathrm{H} 2 \mathrm{O}}$ & 6.82 & 7.23 & 7.95 & 7.92 \\
\hline $\mathrm{EC}\left(\mu \mathrm{S} \mathrm{cm} \mathrm{cm}^{-1}\right)$ & 377 & 345 & 454 & 404 \\
\hline Ash (\%) & 91.90 & 92.40 & 91.70 & 90.90 \\
\hline $\mathrm{CEC}\left(\mathrm{cmol}(+) \mathrm{kg}^{-1}\right)$ & 22.80 & 22.60 & 18.60 & 20.70 \\
\hline Total organic matter (OM, \%) & 4.71 & 11.85 & 4.05 & 15.04 \\
\hline Total C (\%) & 2.79 & 6.93 & 2.36 & 8.74 \\
\hline Total N (\%) & 0.22 & 0.23 & 0.11 & 0.12 \\
\hline Total carbonate (\%) & n.d. & n.d. & 3.60 & 3.90 \\
\hline DOC $\left(\mathrm{mg} \mathrm{g}^{-1}\right)$ & 0.80 & 0.67 & 0.35 & 0.19 \\
\hline Available P (mg. $\left.\mathrm{kg}^{-1}\right)$ & 31.00 & 40.10 & 37.21 & 56.17 \\
\hline Exchangeable $\mathrm{K}\left(\mathrm{cmol}(+) \mathrm{kg}^{-1}\right)$ & 1.19 & 0.99 & 1.11 & 1.03 \\
\hline Exchangeable $\mathrm{Ca}\left(\mathrm{cmol}(+) \mathrm{kg}^{-1}\right)$ & 10.66 & 12.49 & 20.02 & 20.53 \\
\hline Exchangeable $\mathrm{Mg}\left(\mathrm{cmol}(+) \mathrm{kg}^{-1}\right)$ & 2.54 & 2.54 & 2.08 & 2.26 \\
\hline USDA texture & Sandy Loam & & Sandy Loam & \\
\hline \multicolumn{5}{|c|}{ Total PTE concentration ( $\mathrm{mg} \cdot \mathrm{kg}^{-1}$ ) } \\
\hline Total Sb & 1.31 & & 18.88 & \\
\hline Total As & 31.83 & & 39.34 & \\
\hline Total Cd & 4.75 & & 74.03 & \\
\hline Total Fe & 3274 & & 3670 & \\
\hline Total Mn & 626.7 & & 1245 & \\
\hline Total $\mathrm{Pb}$ & 317.67 & & 1899 & \\
\hline Total $\mathrm{Cu}$ & 41.13 & & 136.5 & \\
\hline Total Zn & 622.2 & & 3803 & \\
\hline
\end{tabular}

Data from Manzano et al. (2020). BCH, biochar; PTE, potentially toxic elements. 
Effective amendments are able to immobilize PTE through different mechanisms encompassing surface adsorption (by inner and outer sphere complexation), structural incorporation and/or precipitation (Castaldi et al., 2011, 2015; Silvetti et al., 2017). As mentioned before, this is an essential prerequisite to facilitate and stimulate plant growth in PTE contaminated soils. Common soil PTE include oxyanion (e.g. arsenates, antimonate) and cationic species (e.g. lead, copper, cadmium, zinc) which show a different affinity (i.e. binding capacity) for the functional groups present on the amendment surfaces. This makes very challenging the selection of effective amendments for the immobilization of anionic and cationic PTE co-occurring in soil.

\section{Influence of amendments on labile potentially toxic elements in oxyanionic form}

Single step and/or sequential extraction procedures can be used to assess the amendments influence on labile and potentially bioavailable $\mathrm{As}$ and $\mathrm{Sb}$ oxyanions [i.e. $\mathrm{H}_{2} \mathrm{AsO}_{4}{ }^{-}, \mathrm{HAsO}_{4}{ }^{2-}$ and $\mathrm{SbOH}_{6}{ }^{-}$] (e.g.; Wenzel et al., 2001, Van Vleek et al., 2011; Tan et al., 2018). For instance, the sequential extraction procedure of Wenzel et al. (2001) requires that soil samples are treated with $\left(\mathrm{NH}_{4}\right)_{2} \mathrm{SO}_{4}$ solutions to extract the non-specifically sorbed anionic PTE (Fraction 1). Then, the same soil samples are treated with $\mathrm{NH}_{4} \mathrm{H}_{2} \mathrm{PO}_{4}$ solutions to extract the specifically sorbed As and $\mathrm{Sb}$ (Fraction 2); subsequently they are treated with $\mathrm{NH}_{4}{ }^{+}$-oxalate buffer solutions to extract the PTE associated with amorphous and poorly crystalline $\mathrm{Fe}$ and $\mathrm{Al}$ hydrous oxides (Fraction 3). Finally, soil samples are treated with $\mathrm{NH}_{4}{ }^{+}$-oxalate buffer and ascorbic acid solution to extract $\mathrm{As}$ and $\mathrm{Sb}$ associated with well-crystallized Fe and Al hydrous oxides (Fraction 4). After the last step of the sequential extractions, residual PTE in soil are determined after acid digestion with $\mathrm{H}_{2} \mathrm{O}_{2}$ and $\mathrm{HNO}_{3}+\mathrm{HCl}$ (3:1 ratio).

Single step and/or sequential extraction procedures, despite accepted limitations (Nirel and Morel, 1990), can provide useful evidence on PTE distribution in soil (i.e. quantify mobile and less mobile fractions) after amendment addition.

\section{Municipal solid waste compost}

Several studies showed an increase of labile As in polluted soils treated with MSWC (e.g. Manzano et al., 2016). For example, exchangeable and water-soluble As increased (>65\% compared to untreated soil) in an ex-mining soil treated with $4 \% \mathrm{w} / \mathrm{w}$ MSWC (Manzano et al., 2016). This was explained with: i) the competition between low molecular weight dissolved organic anions within MSWC and As for the same retention sites in soil (Tandy et al., 2009); ii) the potential of specific inorganic anions in compost (e.g. phosphates) to displace As from Fe-oxide phases (Fitz and Wenzel, 2002); iii) the formation of As-(Me)-DOC soluble complexes (note that the soil was co-contaminated by As and metals such as $\mathrm{Pb}, \mathrm{Cd}$, and $\mathrm{Zn}$; Manzano et al., 2016). However, other studies showed that compost had no obvious effect on watersoluble and easily exchangeable $\mathrm{As}$ and $\mathrm{Sb}$, and no mobilization was observed (Garau et al., 2017; Garau et al., 2019b). In particular, Garau et al. (2019b) showed that water-soluble and exchangeable As in a multi PTE polluted soil did not significantly differ in MSWC-treated and untreated soils; while $\mathrm{Sb}$ significantly decreased in treated soil with respect to control (e.g. $<19 \%)$. Likewise, a significant decrease of labile $\mathrm{Sb}$ and As was also recorded by Abou Jaoude et al. (2020) after MSWC addition (3\% $\mathrm{w} / \mathrm{w})$ to different PTE-contaminated soils.

\section{Red muds}

RM addition to a PTE-polluted soil gave a significant decrease of water-soluble As even if the exchangeable As increased (Figure 1; Garau et al., 2011). RM is mainly a complex mixture of $\mathrm{Fe} / \mathrm{Al}$ (hydr)oxides such as hematite, gibbsite, boehmite and others (Castaldi et al., 2011) which show a great affinity for arsenates. These can be immobilized on RM surfaces by weak (e.g. electrostatic) or more stable (bidentate or binuclear) interactions (Castaldi et al., 2011). Such RM effect on water-soluble As was not observed in other studies (e.g. Garau et al., 2014) where, however, water-soluble and exchangeable As were extracted in a single step and could not be discriminated. Therefore, this does not rule out the possibility of a reduction of water-soluble As triggered by RM.

Concerning the immobilization of soil Sb by RM, very few reports can be found in literature. Tandy et al. (2017) showed that high amounts (i.e. 12.5:50 RM to soil ratio, w/w) of RM-based amendments (i.e. ViroSoil ${ }^{\mathrm{TM}}$ ) were effective at reducing $\mathrm{Sb}$ leaching in moderately contaminated shooting range soils. Similar findings were reported by Sanderson et al. (2015) which showed a reduction of water-extractable $\mathrm{Sb}$ (greater than $50 \%$ in the four shooting range soils analysed) after the addition of neutralized (with gypsum) RM at $0.5 \%(\mathrm{w} / \mathrm{w})$.

\section{Water treatments residuals}

Labile As generally decreased in soils amended with Fe-rich WTR, likely as a consequence of stable complexation of As by $\mathrm{Fe}$ (hydr)oxides (Fendorf et al., 2010; Castaldi et al., 2014; Garau et al., 2014; Nagar et al., 2015; Manzano et al., 2016). For instance, an approximate $27 \%$ reduction ( $v s$ control) of labile As was observed in a WTR-treated soil by Garau et al. (2014). By contrast, no obvious effect of WTR on labile Sb was observed in other studies (e.g. Garau et al., 2017). However, it should be noted that in this latter case, total $\mathrm{Sb}$ in soil was low $\left(\sim 100 \mathrm{mg} \mathrm{kg}^{-1}\right)$ and WTR was mixed with MSWC in a 1:1 ratio (w/w), which could have masked the actual WTR effect.

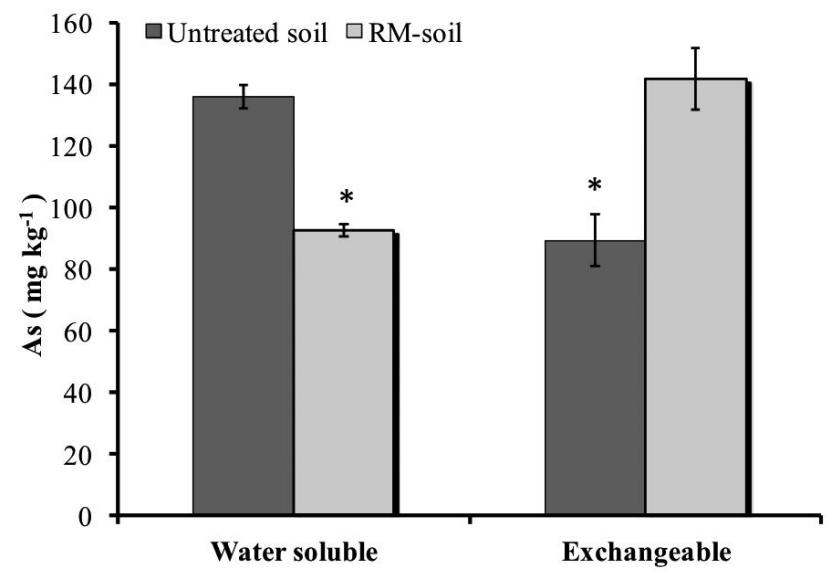

Figure 1. Water soluble and exchangeable As fractions extracted from an untreated and a red muds $(\mathrm{RM})$-treated potentially toxic elements-polluted soil. Red mud was added at $4 \%(w / w)$ rate. Mean values \pm standard deviations (error bars) are reported. For each fraction asterisks denote statistically significant differences (Student's t-test; $\mathbf{P}<0.05)$. Data from Garau et al. (2011). 


\section{Biochar}

A decrease of labile As and $\mathrm{Sb}$ in $\mathrm{BCH}$-treated soils has been detected by Abou Jaoude et al. (2020). In particular, these authors reported a significant decrease of water soluble and exchangeable As and $\mathrm{Sb}$ (up to $\sim 48$ and $33 \%$ respectively) in PTE-polluted soils treated with $3 \%(\mathrm{w} / \mathrm{w}) \mathrm{BCH}$, with respect to unamended soils. Such decreases suggested a strong binding affinity of both PTE with $\mathrm{BCH}$. This might be due to the presence of amorphous Fe or $\mathrm{Al}$ (hydr)oxides within the biochar and to their well-known affinity towards anionic species in soil (Castaldi et al., 2014; Fang et al., 2016; Qiao et al., 2018; Abou Jaoude et al., 2020).

\section{Influence of amendments on labile potentially toxic elements in cationic form}

Likewise $\mathrm{As}$ and $\mathrm{Sb}$, the mobility and potential bioavailability in soil of metal contaminants (e.g. $\mathrm{Pb}, \mathrm{Cd}, \mathrm{Cu}, \mathrm{Cr}, \mathrm{Ni}$ and $\mathrm{Zn}$ ) can be assessed using single step or sequential extraction procedures. Note that the very different characteristics of metal cations and oxyanion contaminants in soil require diverse extractants and sequential extraction procedures, e.g. Wenzel et al. (2001) for anionic PTE such as As and Sb, Tessier et al. (1979), Basta and Gradwhol (2000), Rao et al. (2008) for metal cations such as Pb, $\mathrm{Cu}, \mathrm{Zn}, \mathrm{Cd}$ and $\mathrm{Ni}$. Regarding the sequential extraction of cationic PTE proposed by Basta and Gradwhol (2000), soil samples are first treated with $\mathrm{Ca}\left(\mathrm{NO}_{3}\right)_{2}$ solution to extract metal (Me)exchangeable pool (Fraction 1); afterwards, the same soil samples are treated with $\mathrm{NaOAc}$ solutions to extract Me forming weak surface complexes (Fraction 2); finally, soil samples are treated with $\mathrm{Na}_{2}$ EDTA solutions to extract surface complexed and precipitated Me (Fraction 3). After the last step of the sequential extractions, residual $\mathrm{PTE}$ in soil are determined after acid digestion with $\mathrm{H}_{2} \mathrm{O}_{2}$ and $\mathrm{HNO}_{3}+\mathrm{HCl}$ (3:1 ratio).

\section{Municipal solid waste compost}

Compost addition (especially when added at high rate, e.g. 4 or $10 \% \mathrm{w} / \mathrm{w})$ decreased significantly water-soluble and readily exchangeable $\mathrm{PTE}$ in soil, e.g. $\mathrm{Pb}, \mathrm{Cu}, \mathrm{Zn}, \mathrm{Cd}$, and $\mathrm{Ni}$ (Castaldi et al., 2005; Manzano et al., 2016; Garau et al., 2017; Abou Jaoude et al., 2019; Garau et al., 2019b); as for As and Sb, this is relevant since these fractions represent the most labile and potentially bioavailable PTE pool (Manzano et al., 2016). Garau et al. (2019b) observed that MSWC decreased labile Cd by $32 \%$ and $47 \%$ when $2 \%$ and $4 \%(\mathrm{w} / \mathrm{w})$ compost respectively was added to a strongly polluted mining soil (Figure 2). Such decreases, as well as those observed for other metal cations, could be ascribed to the capacity of MSWC to retain PTE through specific adsorption mechanisms (Park et al., 2011; Garau et al., 2014), as well as to the involvement of compost water-soluble fraction in the formation of poorly soluble PTE-precipitates (Castaldi et al., 2005, 2015, 2017; Park et al., 2011; Garau et al., 2014, 2017; Silvetti et al., 2017; Manzano et al., 2016). In this sense, it was recently shown that phosphate, chloride and sulphate anions within MSWC were able to precipitate $\mathrm{Pb}$ and $\mathrm{Cu}$ ions present in solution (Castaldi et al., 2017). Also, the $\mathrm{pH}$ increase which occurred in compost-amended soils likely favoured: i) the deprotonation of specific functional groups of OM (e.g. carboxyl groups) eventually leading to an increase of stable (i.e. inner sphere) PTE complexes (Wang and Mulligan, 2009); ii) the formation of PTE precipitates in the form of metal oxides or hydroxides. Nevertheless, some studies reported an increase of water soluble and exchangeable $\mathrm{Zn}$ and $\mathrm{Cd}$ (e.g. Beesley and Dickinson, 2010; Manzano et al., 2016; Abou Jaoude et al., 2019) after MSWC addition to soil. This phenomenon, which was also observed for As, was explained with the formation of soluble complexes between $\mathrm{Zn}$ or $\mathrm{Cd}$ and DOC compounds (Martínez et al., 2003). Besides, it cannot be excluded that divalent metal cations abundant in MSWC (such as $\mathrm{Ca}$ and $\mathrm{Mg}$ ), and readily released in the soil solution, could have affected the mobility of $\mathrm{Zn}$ by means of ion exchange (Branzini and Zubillaga, 2012; Manzano et al., 2016).

\section{Red muds}

Garau et al. (2014) detected a significant increase of water-soluble $\mathrm{Zn}, \mathrm{Cu}$ and $\mathrm{Cd}$ in a contaminated soil amended with $\mathrm{RM}$ (Figure 3). This was explained by the increased concentration of water-soluble metal-organic complexes deriving from the alkaline dispersion of native soil organic matter induced by RM (Garau et al., 2011, 2014). However, Garau et al. (2007) observed a high reduction of water-soluble and exchangeable $\mathrm{Cd}, \mathrm{Pb}$ and $\mathrm{Zn}$ in an acidic contaminated soil ( $\mathrm{pH} 4.2)$ treated with $4 \%$ (w/w) RM. For instance, water-soluble $\mathrm{Zn}$ decreased from 87 to $8.7 \mathrm{mg} \mathrm{kg}^{-1}$ soil, while exchangeable $\mathrm{Zn}$ reduced from 244 to $15 \mathrm{mg} \mathrm{kg}^{-1}$. This was explained with the increase in $\mathrm{pH}$ (from 4.2 to 7.1 ) in this RMtreated soil, which favoured the precipitation of Me oxides or hydroxides, as well as with metal adsorption by variably charged colloids such as Fe and Al (hydr)oxides within RM (Taneez and Hurel, 2019).

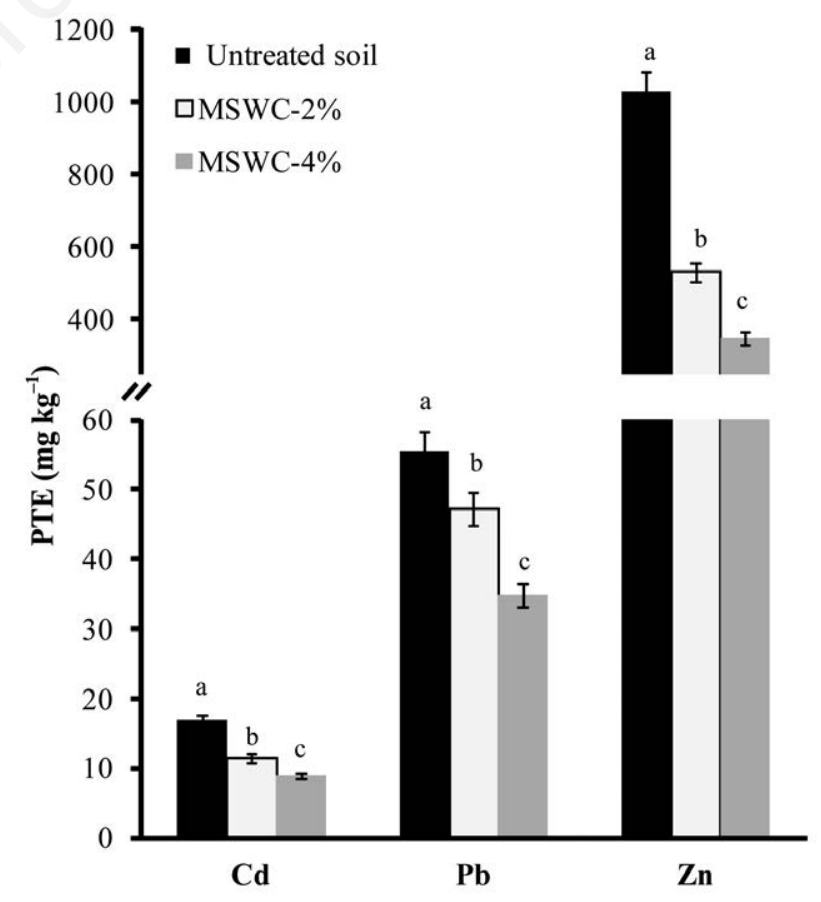

Figure 2. Water soluble $\mathrm{Cd}, \mathrm{Zn}$ and $\mathrm{Pb}$ fractions extracted from an untreated potentially toxic elements (PTE)-polluted soil and from the same soil treated with 2 and $4 \%(w / w)$ municipal solid waste compost (MSWC). Mean values \pm standard deviations (error bars) are reported. For each PTE, different letter on top of each bar denote statistically significant differences (Fisher's least significant different test; $\mathrm{P}<0.05)$. Data from Garau et al. (2019b). 


\section{Water treatment residuals}

The impact of WTR on labile Me in soil was variable. In particular, WTR reduced or did not change significantly water-soluble and exchangeable PTE such as $\mathrm{Pb}, \mathrm{Zn}$ and $\mathrm{Cu}$ (Garau et al., 2014; Manzano et al., 2016). The reduction was mainly explained with the capacity of the organic and inorganic components of WTR to chemically adsorb PTE (i.e. Park et al., 2011; Garau et al., 2014). Importantly, we are not aware of labile PTE increases after WTR addition.

\section{Biochar}

Biochar was able to significantly reduce water-soluble and readily exchangeable PTE in polluted soils (Abou Jaoude et al., 2020; Manzano et al., 2020). Manzano et al. (2020) showed that labile $\mathrm{Cd}, \mathrm{Zn}$ and $\mathrm{Pb}$ were reduced by $29 \%, 55 \%$ and $79 \%$ in a multi PTE polluted soil treated with $5 \%(\mathrm{w} / \mathrm{w}) \mathrm{BCH}$. This was explained by different factors such as: i) the liming effect of $\mathrm{BCH}$ (Houben and Sonnet, 2015); ii) the PTEs complexing capacities of $\mathrm{BCH}$ by means of its carboxylic and phenolic functional groups (Abou Jaoude et al., 2020; Qiao et al., 2018); iii) the influence of $\mathrm{BCH}$ inorganic components $\left(\mathrm{CO}_{3}{ }^{2-}, \mathrm{OH}^{-}, \mathrm{PO}_{4}{ }^{3-}\right)$ in the formation of PTE precipitates, e.g. lead carbonates $\left[\mathrm{PbCO}_{3}\right.$ and $\left.\mathrm{Pb}_{3}\left(\mathrm{CO}_{3}\right)_{2}(\mathrm{OH})_{2}\right]$ and lead phosphates $\left[\mathrm{Pb}_{5}\left(\mathrm{PO}_{4}\right)_{3}(\mathrm{OH}, \mathrm{Cl})\right.$ and $\left.\mathrm{Pb}_{9}\left(\mathrm{PO}_{4}\right)_{6}\right]$ (i.e. Cao et al., 2003; Beesley et al., 2014; Bandara et al., 2016; Manzano et al., 2020; Abou Jaoude et al., 2020).

\section{Influence of municipal solid waste compost, red muds, water treatment residuals and biochar on the heterotrophic microbial community and bio- chemical functioning in potentially toxic elements- contaminated soils}

Most often, the selection of an amendment for the in-situ treatment of contaminated soils is primarily based on its chemical performance, i.e. the ability to reduce the concentration of labile PTE. By contrast, additional effects such as the amendment impact on soil microbial abundance, diversity and functionality are often neglected as well as the impact of the amendment on the soil microbial community. However, it is widely recognized that the soil microbial component can affect many key ecosystem processes, e.g. the biogeochemical cycle of plant nutrients, as well as stimulate plant growth (Garau et al., 2005). Therefore, the maintenance and/or improvement of soil microbial abundance, diversity and functionality following amendment addition should be of primary importance to support ecosystem services and possibly allow for increased plant yield (Garau et al., 2014, 2017, 2019a).

Readily culturable heterotrophic bacteria and fungi are a small component of the total soil microbial community (1-5\%; van Elsas et al., 2006), yet their relevance in terms of both biomass and activity can be much greater. As pointed out by Ellis et al. (2003), a positive correlation has been shown between activity and cell size, cell size and culturability, and activity and culturability. Moreover, given the very small size of the numerically dominant unculturable microbial cells in soil, these latter are not expected to contribute greatly to soil microbial biomass or metabolic activity (Ellis et al., 2003). For these reasons, the number of readily culturable microorganisms can be used to estimate the potentially active microbial populations in soil, i.e. those involved in soil organic matter turnover and in the cycling of elements essential for plant growth, e.g. N and P (e.g. Timms-Wilson et al., 2006; Mohapatra,
2008; Ventorino et al., 2018; Garau et al., 2019a).

Soil enzymes (mostly, even if not exclusively, released by microbial cells) play a central role in such processes mediating and regulating the organic matter decomposition and contributing to soil fertility (Oliveira and Pampulha, 2006; Bhattacharyya et al., 2008). Given their sensitivity to PTE, soil enzyme activities are often reduced in contaminated soils and this is expected to negatively affect soil fertility and plant growth (Bhattacharyya et al., 2008; Oliveira and Pampulha, 2006; Garau et al., 2019a). Identifying suitable amendments, able to increase heterotrophic microbial populations and stimulate biochemical functioning in PTE-contaminated soils, can be therefore relevant for improving soil fertility and establishing higher crop yields in contaminated environments.

\section{Municipal solid waste compost}

The addition of MSWC or mixed amendments containing compost, to PTE-contaminated soils generally increased the number of culturable heterotrophic bacteria (Garau et al., 2017, 2019a). Bacterial number (expressed as $\log _{10} \mathrm{CFU} \mathrm{g}^{-1}$ soil) increased from 5.81 to 6.61 after the amendment of a mining technosol contaminated by $\mathrm{Sb}, \mathrm{Pb}, \mathrm{Cd}$ and $\mathrm{Zn}$ with $1 \% \mathrm{MSWC}+1 \% \mathrm{WTR}$ (Garau et al., 2017). The same effect was observed on culturable fungi (from 4.79 to $5.00 \log _{10} \mathrm{CFU} \mathrm{g}{ }^{-1}$ soil) and actinomycetes (from 5.57 to 6.19 $\log _{10} \mathrm{CFU} \mathrm{g}^{-1}$ soil). Similar trends were observed in different soils heavily contaminated with As (up to 22,661 mg kg-1) and variable amounts of co-occurring metals, i.e. $\mathrm{Pb}, \mathrm{Zn}$, and $\mathrm{Cu}$ (Garau et al., 2019a). In this case, MSWC was the most effective amendment at increasing the population size of total culturable

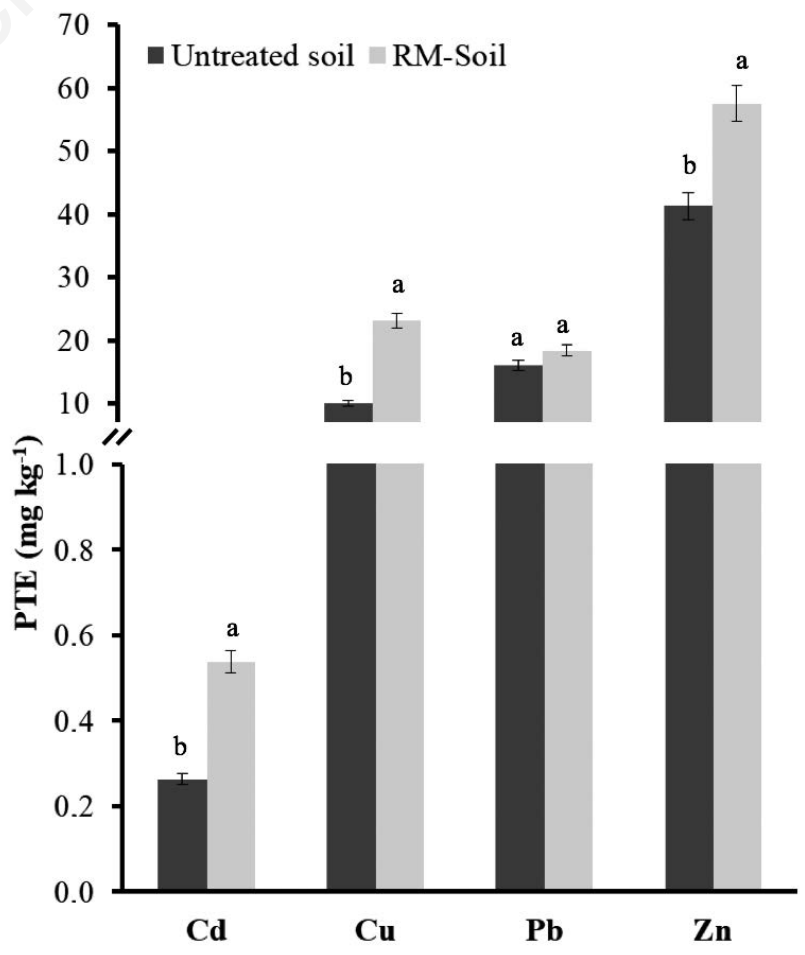

Figure 3. Water soluble $\mathrm{Cd}, \mathrm{Cu}, \mathrm{Pb}$ and $\mathrm{Zn}$ extracted from an untreated potentially toxic elements (PTE)-polluted soil and from the same soil treated with red muds $(\mathrm{RM})$ at $3 \%$ rate. Mean values \pm standard deviations (error bars) are reported. For each PTE, different letter on top of each bar denote statistically significant differences (Fisher's least significant different test; $\mathbf{P}<0.05$ ). Data from Garau et al. (2014). 
bacteria (soil treatments with WTR and MSWC+WTR were also included in the study; Figure 4), while the number of fungi generally decreased (up to $<14 \%$; Garau et al., 2019a). Overall, this was explained by a reduction of labile PTE in soil, due to compost fixing abilities, and to the release of $\mathrm{C}$ compounds from MSWC which sustained microbial growth in amended soils.

These results were supported by an improved biochemical functioning in amended soils. In particular, dehydrogenase activity (DHG), which reflects the capacity of several intracellular enzymes to oxidize organic molecules, was increased up to $\sim 20$ fold after 4\% (w/w) MSWC addition (Garau et al., 2019a, 2019b; Figure 5). However, both inhibitory and stimulating effects were observed for urease activity (URE) that catalyses a specific step of the $\mathrm{N}$ cycle, i.e. urea conversion to $\mathrm{NH}_{4}{ }^{+}$and $\mathrm{CO}_{2}$ (Speir et al., 1999; Bhattacharyya et al., 2008; Sigurdarson et al., 2018). For instance, Garau et al. (2019b) observed that URE decreased by $32 \%$ and $60 \%$ in polluted soils amended with $2 \%$ and $4 \%(\mathrm{w} / \mathrm{w})$ MSWC. This appeared in contrast with the lower potential bioavailability of PTE observed in the amended soils but could be explained by the formation of humus-enzyme complexes with reduced catalytic activities (Pascual et al., 2002). Moreover, the inorganic $\mathrm{N}$ released by MSWC could have inhibited urease synthesis by soil microbial populations contributing to explain the reduced URE activity detected in amended soils (Castaldi et al., 2009a; Garau et al., 2019b). Nonetheless, increased URE activity values were observed in contaminated soils treated with MSWC (Abou Jaoude et al., 2019; Garau et al., 2019a). In particular, Garau et al. (2019a) showed that URE activity in compost treated soils increased up to 7 .4-fold, suggesting that PTE contamination can have negative influences on soil N cycle and that MSWC addition can be helpful to alleviate and/or reverse such negative impact (Bhattacharyya et al., 2008; Abou Jaoude et al., 2019).

The $\beta$-glucosidases activity (GLU), due to extracellular enzymes involved in soil $\mathrm{C}$ cycle (i.e. they cleave $\beta 1 \rightarrow 4$ bonds linking two glucose or glucose substituted molecules; Alvarenga et al., 2008; Bastida et al., 2012), was significantly enhanced in polluted soils treated with MSWC (Abou Jaoude et al., 2019; Garau et al. 2019a, 2019b). Abou Jaoude et al. (2019) highlighted MSWC as the most effective amendment at favouring GLU, i.e. it stimulated a 117-fold increase of GLU with respect to control soil. This was likely due to the increase of labile $\mathrm{C}$ in amended soils (Alvarenga et al., 2008; Novak et al., 2018) and to a decrease of labile PTE (Bhattacharyya et al., 2008; Garau et al., 2019b). As for URE, other reports indicated that GLU activity decreased in MSWC-treated soils (Miller et al., 1998; Garau et al., 2014, 2017, $2019 \mathrm{a})$. Considering that fungi are the predominant source of $\beta$ glucosidases in soil, the reduced GLU activity could be due to an altered fungal/bacterial ratio, where bacteria prevailed in MSWCtreated soils (Garau et al., 2019a).

\section{Red muds}

Red mud addition caused a significant increase of soil microbial biomass-C and fast-growing heterotrophic bacteria in PTEcontaminated soils (e.g. Garau et al., 2007, 2014). This latter microbial population increased up to 10 -fold in an RM-treated soil $(4 \% \mathrm{w} / \mathrm{w})$ with respect to the control (e.g. Garau et al., 2007, 2011, 2014). Such increases were not simply due to a reduction of labile PTE and/or to an improvement of other soil chemical parameters which could promote microbial growth (e.g. soil $\mathrm{pH})$, but also to the ability of RM to disperse the stable soil organic matter and increase the DOC in soil pore water (Lombi et al., 2004; Garau et al., 2011, 2014). As opposed to culturable bacteria, the number of heterotrophic fungi decreased significantly or did not show any substantial variation in size after the addition of RM (Garau et al., $2007,2014)$. As previously mentioned, this was apparently due to the RM influence on soil $\mathrm{pH}$ which favoured the growth of bacteria at the expenses of fungi (Strickland and Rousk, 2010; Garau et al., 2014).

Increased DHG activity ( $\sim 43-60 \%)$ was observed by Garau $e t$ al. $(2007,2011,2014)$ in RM-treated soils and this was the result of a higher bacterial abundance probably due to the higher PTEimmobilization in amended soils. In this regard, a highly significant correlation was found between DHG and culturable heterotrophic bacteria $(\mathrm{r}=0.86, \mathrm{P}<0.0001)$ in different PTE-contami-

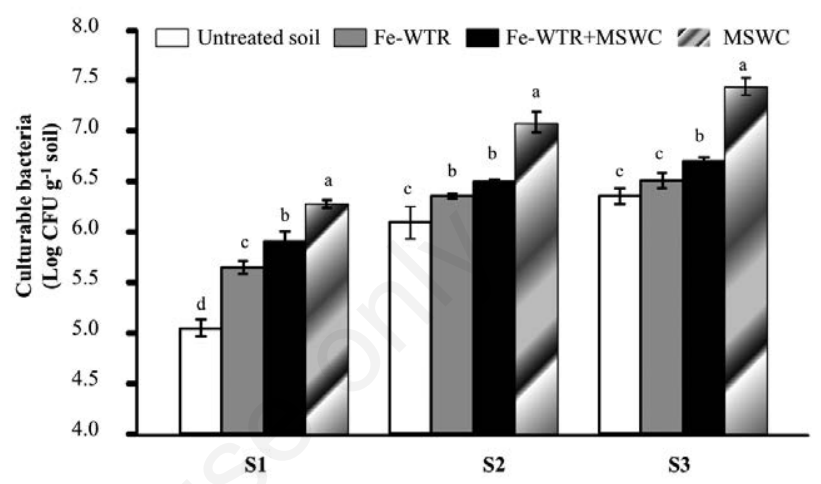

Figure 4. Total culturable heterotrophic bacteria in different untreated potentially toxic elements (PTE)-contaminated soils (S1, S2 and S3) [untreated] and in the same soils treated with water treatment residuals (WTR) at $2 \%(w / w)$, WTR at $1 \%(w / w)$ + municipal solid waste compost (MSWC) at $2 \%(w / w)$ and MSWC at 4\% (w/w). For each soil, different letter on top of each bar denote statistically significant differences (Tukey-Kramer multiple comparison test; $\mathrm{P}<0.05)$. Data from Garau et al. (2019a). Total PTE content in S1, S2 and S3 soils is reported in Table 2.

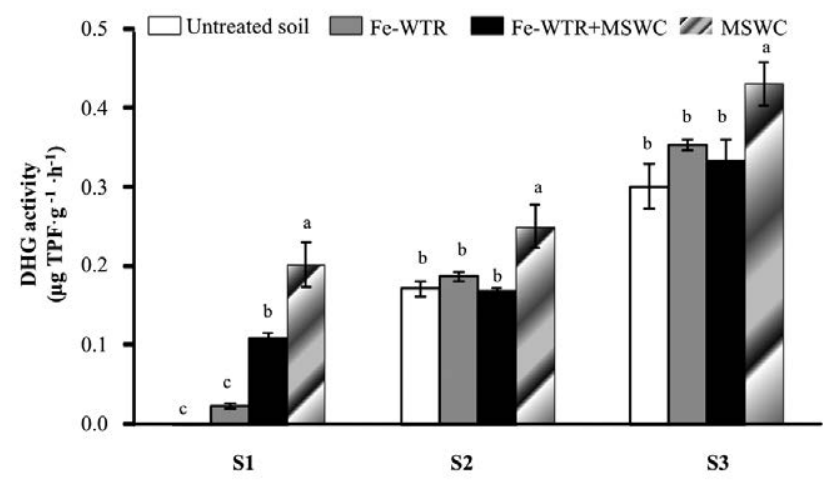

Figure 5. Dehydrogenase (DHG) activity in different untreated potentially toxic elements (PTE)-contaminated soils (S1, S2 and S3) [untreated] and in the same soils treated with water treatment residuals (WTR) at $2 \%(w / w)$, municipal solid waste compost (MSWC) at $4 \%(w / w)$ and WTR at $1 \%(w / w)+$ MSWC at $2 \%$ $(w / w)$. For each soil, different letter on top of each bar denote statistically significant differences (Tukey-Kramer multiple comparison test; $\mathrm{P}<0.05)$. Data from Garau et al. (2019a). Total PTE content in S1, S2 and S3 soils is reported in Table 2. TPF, triphenyl formazan. 
nated soils treated with different organic-based amendments (Garau et al., 2019a).

Evident positive effects of RM on urease activity were shown (Bhattacharyya et al., 2008; Garau et al., 2007, 2011, 2014). For instance, Garau et al. (2011) showed that in untreated PTE polluted soil URE activity was $\sim 12$-fold lower with respect to RM- treated soil. GLU activity on the contrary significantly decreased (e.g. by $\sim 30-50 \%$ compared to the untreated soil; Garau et al., 2007, 2014) or was unaffected (Garau et al., 2011) in soils treated with RM.

\section{Water treatment residuals}

The soil microbial biomass-C remained unchanged after WTR addition (Garau et al., 2014), while the number of culturable heterotrophic bacteria and actinomycetes increased significantly (Garau et al., 2014, 2017, 2019a; Figure 4). This was explained by the greater availability in the amended soil of easily metabolisable carbon sources deriving from the OM within WTR as suggested by the significant DOC and OM increase in the amended soils (Garau et al., 2011, 2017). As opposed to culturable bacteria, the number of heterotrophic fungi decreased significantly after the WTR addition (Garau et al., 2014), while substantial increases were observed elsewhere (Garau et al., 2017, 2019a).

DHG increased significantly after WTR addition (e.g. approx. 6 and 12 -fold higher at 1 and $2 \%$ amendment rate with respect to unamended soil) (Garau et al., 2017). However, it should be said that in this case WTR were mixed with MSWC. However, DHG increases after WTR amendment were observed in other studies (e.g. Garau et al., 2014) when null effects were also observed (Garau et al., 2019a; Figure 5). Also URE was stimulated in PTEpolluted soils amended with WTR (Garau et al., 2014, 2017, 2019a). As for RM-treated soils, GLU activity significantly decreased or was unaffected in soils treated with WTR (Garau et al., 2014, 2017, 2019a). This decrease appeared strongly associated with the bacteria increase in treated soils, as observed in other amended soils (Garau et al., 2014, 2017, 2019a).

\section{Biochar}

The influence of $\mathrm{BCH}$ on heterotrophic microbial communities in PTE-contaminated soil was poorly investigated so far. However, preliminary results from a recent (unpublished) study carried out in our laboratory indicated that 2.5 and $5.0 \%$ softwood-derived $\mathrm{BCH}$ (obtained at high pyrolysis temperature, i.e. $800^{\circ} \mathrm{C}$; Manzano et al., 2020) did not change the number of culturable heteretrophic bacteria, fungi and actynomicetes in a mining soil contaminated by $\mathrm{Pb}, \mathrm{Cd}$ and $\mathrm{Zn}$. However, $\mathrm{BCH}$ obtained from different organic biomasses (e.g. corn cob), at lower pyrolysis temperature, i.e. $450^{\circ} \mathrm{C}$, significantly increased soil culturable bacterial (Jiang et al., 2017). Such contrasting results could be explained by the different DOC content of $\mathrm{BCH}$ obtained at different temperatures (i.e. high DOC for low-temperature $\mathrm{BCH}$ and low DOC for high-temperature BCH; Abou Jaoude et al., 2020; Manzano et al., 2020).

Abou Jaoude et al. (2020), observed significant DHG increases in contaminated soils amended with low-temperature BCH supporting our previous hypothesis. For instance, DHG increased up to $49 \%$ when the polluted soil was treated with $3 \%(\mathrm{w} / \mathrm{w}) \mathrm{BCH}$. Also URE and GLU activity increased in soils treated with biochar. Particularly, the addition of 3\% BCH favoured an increase of GLU of $\sim 17 \%$ compared to the untreated control (Abou Jaoude et al., 2020).

\section{Influence of municipal solid waste compost, red muds, water treatment residuals and biochar on plant growth in potentially toxic elements-contam- inated soils}

As previously mentioned, soil chemical, biochemical or microbial properties could be improved by amendment addition, but this does not necessarily imply a better plant growth or a reduced PTE uptake (e.g. Garau et al., 2014). For this reason, the results of several plant growth experiments can be useful to obtain a comprehensive overview of the impact of MSWC, RM, WTR and BCH on crop yield and PTE uptake in contaminated soils. The reported use of edible species (e.g. bean, pea, wheat and others) in these experiments is to be considered within this context and not as an agricultural option to pursue in PTE-contaminated soils (which is not permitted by any national legislation). As anticipated, such soils could be more effectively (and safely) used for non-food/feed productions allowing soil recovery and income generation.

Plant growth, estimated by root and shoot dry weight, was generally highly influenced by soil, contamination type and amendment addition, supporting the view that the amendment effectiveness needs to be evaluated case by case. Generally, adding MSWC, WTR, RM and BCH to PTE-polluted soils had a positive impact on plant growth even if some important exceptions were also reported (Castaldi et al., 2005, 2009b, 2018; Garau et al., 2017; Garau et al., 2020).

\section{Municipal solid waste compost}

White lupin grown in a PTE-polluted soil treated with a high rate of compost $(10 \% \mathrm{w} / \mathrm{w})$ showed a significantly higher biomass production with respect to untreated soil. In particular, the above ground and roots biomass increased by 3.6-fold and 1.4-fold respectively in the amended soil (Castaldi et al., 2005). Garau et al. (2017) observed that root dry weight of H. italicum increased by approx. $45 \%$ and $73 \%$ after amendment of a PTE-contaminated technosol with MSWC and WTR at $1 \%$ and $2 \%$ rate respectively, and very similar increases were observed for shoot dry weight. Also, P. australis and A. donax yields were significantly increased in a polluted soil (up to 22,600 $\mathrm{mg} \mathrm{As} \mathrm{kg}^{-1}$ ) amended with MSWC, i.e. by $\sim 41 \%$ and $67 \%$ compared to control plants (Castaldi et al., 2018). Root biomass of C. cardunculus increased by more than 17 fold and 23-fold in polluted soils amended with $2 \%$ and $4 \%(\mathrm{w} / \mathrm{w})$ MSWC respectively, compared to unamended soil, while shoot biomass increased by approx. 5-fold and 10-fold (Garau et al., 2020).

Such positive MSWC influence on plant growth was mainly explained by its PTE-fixing abilities (as discussed previously) which greatly alleviated the toxicity of contaminated soils. However, MSWC alkalinity can also play an important role in the improvement of soil fertility (Castaldi et al., 2018). Finally, the increased CEC, total $\mathrm{OM}$, available $\mathrm{P}$ and total $\mathrm{N}$ observed in MSWC-treated soils had a positive effect on the above-mentioned plant growth, which is overall expected in the majority of soils.

Overall, the above-mentioned plant growth effects were often accompanied by decreased PTE uptake. In addition, the highest concentrations of PTE were generally found in roots, followed by aerial parts, irrespectively of the plant species (Allende et al., 2014; Conesa et al., 2014; Bacchetta et al., 2015; Kouki et al., 2015; Pardo et al., 2016; Pérez-Sirvent et al., 2017; Castaldi et al., 2018). For instance, Castaldi et al. (2005) reported that the concentration of $\mathrm{Pb}$ in the aerial part of white lupin grown in a contami- 
nated compost-amended soil was $87 \%$ lower than that of control plants. Garau et al. (2017) reported that $H$. italicum grown in soils amended with MSWC and WTR showed approximately 50\% reduction in $\mathrm{Sb}$ concentration in roots and shoots (i.e. stem + leaves). The As uptake in the below ground biomass of $P$. australis and $A$. donax, grown in a highly polluted mining soil (up to 22,600 $\mathrm{mg} \mathrm{kg}^{-1}$ As) amended with MSWC, was significantly lower than that of control plants (Castaldi et al., 2018). However, when grown on moderately polluted soils (up to $750 \mathrm{mg} \mathrm{kg}^{-1} \mathrm{As}$ ), As uptake in the belowground biomass was unaffected or slightly increased for plants grown in MSWC-treated soils (Castaldi et al., 2018). By contrast, As accumulation in shoots of $P$. australis and A. donax grown in MSWC-amended soils was comparable and in some cases significantly lower than that observed in plants grown on control soils (Castaldi et al., 2018). Garau et al. (2020) reported a significant decrease in the concentration of different PTE in cardoon tissues grown in soil treated with $2 \%$ and $4 \%$ (w/w) MSWC. For example, As concentration in roots decreased by 11.7 -fold and 8.7-fold, and Sb by 6.7 -fold and 6.5 -fold, in $2 \%$ and $4 \%(\mathrm{w} / \mathrm{w})$ amended soils respectively, compared to control (unamended) roots. Also $\mathrm{Cd}, \mathrm{Cu}, \mathrm{Pb}$, and $\mathrm{Zn}$ uptake was significantly reduced by MSWC amendment (Garau et al., 2020).

\section{Red muds}

The effects on plant growth of RM addition to polluted soils are contrasting based on plant species, soil type and level (and type) of contamination. Castaldi et al. (2009b) reported a positive effect of RM (added at 4\% w/w) on pea and wheat growth in a soil polluted with $\mathrm{Pb}, \mathrm{Cd}$ and $\mathrm{Zn}$. In particular, the above ground biomass of pea and wheat increased by a factor of 1.8 and 5.4 respectively when RM was added to soil. However, some symptoms of leaf chlorosis (followed by necrosis) were observed for plants grown in RM-amended soil (Castaldi et al., 2009b). These could be ascribed to the great affinity of RM for selected elements such as phosphate, which can lead to nutrient deficiency.

By contrast, RM addition to a soil mainly contaminated by As, did not influence wheat growth, while had critical effects on bean germination which was completely inhibited (Garau et al., 2014). In this latter case, the RM influence on plant growth could be explained with the high salt content of the amendment, as well as with high labile As due to RM alkalinity (Garau et al., 2014).

Pea and wheat plants grown on a RM-amended acidic soil accumulated significantly lower amounts of $\mathrm{Pb}, \mathrm{Cd}$ and $\mathrm{Zn}$ compared to control plants (e.g. $<60 \%, 79 \%$ and $93 \%$ of $\mathrm{Pb}, \mathrm{Cd}$ and $\mathrm{Zn}$ in pea plants grown in RM-soil with respect to control plants; Castaldi et al., 2009b). However, a significantly increase of As uptake ( $\sim$-fold) was observed in wheat shoots of plants grown on a RM-treated alkaline soil (Garau et al., 2014).

\section{Water treatment residuals}

Bean and wheat growth in the same PTE-polluted soil treated with $3 \%(\mathrm{w} / \mathrm{w})$ WTR was 2.5 -fold and 1.8-fold greater respectively than that of control plants (Garau et al., 2014). Likewise, WTR significantly promoted root and shoot growth of $A$. donax and $P$. australis in different PTE-contaminated soils (Castaldi et al., 2018), performing in some soil as well as MSWC. We already mentioned the increased yield of $H$. italicum in a technosol contaminated by $\mathrm{Sb}, \mathrm{Pb}, \mathrm{Cd}$, and $\mathrm{Zn}$, and amended with WTR+MSWC (Garau et al., 2017). While the observed plant growth promotion effect could not be entirely attributed to one or another amendment, this latter study indicates that MSWC and WTR can be successfully used to increase crop yield in PTE-contaminated or degraded (i.e. nutrient poor) soils as also supported by other authors (Clarke et al., 2019; Hsu and Hseu, 2011; Zhao et al., 2016, 2018).

As for MSWC, the increased crop yield in WTR-amended soils can be explained by a certain improvement of soil nutrient status, i.e. higher TOC, CEC, total $\mathrm{P}, \mathrm{Ca}$ and $\mathrm{Fe}$ (Table 2), other than a PTE-fixing capability mainly due to its mineral components.

The addition of WTR showed some potential to reduce As uptake in roots and shoots of $A$. donax and P. australis, independently of the As concentration in soil (Castaldi et al., 2018). However, the uptake of As in bean shoots was significantly increased, when compared to control, when plants were grown in a WTR-amended soil (Garau et al., 2014).

\section{Biochar}

Despite some authors reported the phytotoxicity effects (i.e. inhibition of Lepidium sativum L. germination) of some biochars (Buss et al., 2016), there is increasing evidence that $\mathrm{BCH}$ may have a substantial role at increasing plant biomass by increasing soil fertility and reducing labile PTE in contaminated soils (e.g. Ibrahim et al., 2017; Yousaf et al., 2018). The latter research in particular showed that $\mathrm{BCH}$ can significantly stimulate bean and wheat growth while limiting the PTE uptake in plant tissues. Some (unpublished) results from our research group also indicate increased crop yield for tomato (Solanum lycopersicum L.) plants grown in a mining soil amended with $2.5 \%$ and $5.0 \%(\mathrm{w} / \mathrm{w})$ softwood-derived $\mathrm{BCH}$. Interestingly, crop yield was in the order $2.5 \%$ $\mathrm{BCH}>5.0 \% \mathrm{BCH}>$ Control soil (no $\mathrm{BCH}$ added) suggesting that high $\mathrm{BCH}$ amounts can limit plant growth likely because of nutrient retention, as recently highlighted by Manzano et al. (2020).

Taken together, these results highlight an overall effectiveness of MCSW, RM, WTR and BCH at reducing PTE bioavailability and improving soil fertility in polluted soils. However, particular attention should be paid when considering RM as a potential treatment for the recovery of alkaline PTE-contaminated soils. And also, the amounts of BCH added to PTE-contaminated soils should be carefully considered to maximise plant growth and avoid soil nutrient deficiencies. Given that, as a general trend, the roots (and rhizome) of pea, wheat, bean, lupin, giant and common reed, and cardoon accumulated much more PTE than shoots (and this was often increased in treated soils), the selected amendments could be considered for their use in assisted phytostabilization protocols (Zornoza et al., 2002; Castaldi et al., 2005, 2018; Fumagalli et al., 2014; Garau et al., 2017; Gorovtsov et al., 2019; Garau et al., 2020).

\section{Future prospects}

Different prospects can be foreseen for the use of RM, MSWC, WTR and BCH in the recovery of PTE-polluted soils. For instance, their combined use has been poorly considered so far while it could provide better solutions for soil remediation. In particular, MSWC which commonly contains high DOC content could be used in combination with selected $\mathrm{BCH}$ able to adsorb the dissolved organic matter. This would avoid the increase of PTE solubility due to soluble DOC-PTE complex formation (Palansooriya et al., 2020). Likewise, the potentials of modified amendments should be better explored, e.g. sulphur modified $\mathrm{BCH}$ was very effective (more than unmodified control) at stabilizing mercury in soil (Zhao et al., 2020), while phosphorous-modified BCH was very active at fixing cationic and anionic PTE in soil such as $\mathrm{Pb}, \mathrm{Cd}, \mathrm{Cu}$ and As (Zhang et al., 2020). The possibility to use such materials 
as media for the delivery of useful microorganisms in polluted soils, e.g. PGPR (plant growth promoting rhizobacteria) represents another perspective to explore. Finally, it should be noted that most of the studies concerning such amendments have been carried out at the laboratory scale mostly considering short-term effects. Further long-term field studies should be necessary to fully understand the actual perspectives of these amendments in PTE polluted environments.

\section{Conclusions}

By-products generated by the municipal and industrial waste cycle such as MSWC, RM, WTR and $\mathrm{BCH}$, possess valuable physico-chemical characteristics which (with few exceptions) allow their use as strategic amendments for the recovery of the fertility and functionality of PTE-contaminated soils. This is relevant, as it implies a recovery of productivity of such areas which can be devoted to the cultivation of non-food or non-feed crops. Moreover, the use of such amendments can help to reduce the disposal of some of them (e.g. RM) attenuating their negative environmental impact and, importantly, contributing to a circular economy.

Possible critical issues are related to the relatively high amounts added to soil $(3-5 \% \mathrm{w} / \mathrm{w}$ in most of the studies), while the overall availability of the amendments is essentially unlimited, and their cost relatively low in relation to alternative interventions. Another issue which so far has been little addressed is the duration of the amendment effects. This is particularly important for the organic-based materials, MSWC in particular, whose stability and effectiveness could change with time due to microbial decomposition. Moreover, also plant growth over time could influence the PTE-fixing abilities of MSWC, RM, WTR and $\mathrm{BCH}$, and this should be considered.

Overall, MSWC, RM, WTR and BCH can be considered as environmental friendly amendments that can contribute to the robustness of soil and plants, enhancing crop productivity in problematic and underutilized areas such those contaminated by PTE.

\section{References}

Abou Jaoude L, Castaldi P, Nassif N, Pinna MV, Garau G, 2020. Biochar and compost as gentle remediation options for the recovery of trace elements-contaminated soils. Sci. Total Environ. 711:134511.

Abou Jaoude L, Garau, G, Nassif, N, Darwish, T, Castaldi, P, 2019. Metal(loid)s immobilization in soils of Lebanon using municipal solid waste compost: microbial and biochemical impact. Appl. Soil Ecol. 143:134-43.

Adriano DC, Wenzel WW, Vangronsveld J, Bolan NS, 2004. Role of assisted natural remediation in environmental cleanup. Geoderma 122:121-42.

Ahmad T, Ahmad K, Alam M, 2016. Sustainable management of water treatment sludge through 3'R' concept. J. Clean. Prod. 124:1-13.

Allende KL, McCarthy DT, Fletcher TD, 2014. The influence of media type on removal of arsenic, iron and boron from acidic wastewater in horizontal flow wetland microcosms planted with Phragmites australis. Chem. Eng. J. 246:217-28.
Alvarenga P, Gonçalves AP, Fernandes RM, de Varennes A, Vallini G, Duarte E, Cunha-Queda AC, 2008. Evaluation of composts and liming materials in the phytostabilization of a mine soil using perennial ryegrass. Sci. Total Environ. 406:43-56.

Antelo J, Avena M, Fiol S, Lopez R, Arce F, 2005. Effects of pH and ionic strength on the adsorption of phosphate and arsenate at the goethite-water interface. J. Colloid Interface Sci. 285:476-86.

Apak R, Tutem E, Hugul M, Hizal J, 1998. Heavy metal cation retention by unconventional sorbents (red mud and fly ashes). Water Res. 32:430-40.

Bacchetta G, Cappai G, Carucci A, Tamburini E, 2015. Use of native plants for the remediation of abandoned mine sites in Mediterranean semiarid environments. Bull. Environ. Contam. Toxicol. 94:326-33.

Bandara T, Herath I, Kumarathilaka P, Hseu Z, Ok YS, Vithanage M, 2016. Efficacy of woody biomass and biochar for alleviating heavy metal bioavailability in serpentine soil. Environ. Geochem. Health 39:391-401.

Basta N, Gradwohl R, 2000. Estimation of $\mathrm{Cd}, \mathrm{Pb}$, and $\mathrm{Zn}$ bioavailability in smelter contaminated soils by a sequential extraction procedure. J. Soil Contam. 9:149-64.

Basta NT, McGowen SL, 2004. Evaluation of chemical immobilization treatments for reducing heavy metal transport in a smelter-contaminated soil. Environ. Pollut. 127:73-82.

Bastida F, Jindo K, Moreno JL, Hernández T, García C, 2012. Effects of organic amendments on soil carbon fractions, enzyme activity and humus-enzyme complexes under semiarid conditions. Eur. J. Soil Biol. 53:94-102.

Beesley L, Dickinson N, 2010. Carbon and trace element mobility in an urban soil amended with green waste compost. J. Soils Sediments 10:215-22.

Beesley L, Inneh OS, Norton GJ, Jimenez EM, Pardo T, Clemente R, Dawson JC, 2014. Assessing the influence of compost and biochar amendments on the mobility and toxicity of metals and arsenic in a naturally contaminated mine soil. Environ. Pollut. 186:195-202.

Beesley L, Marmiroli M, 2011. The immobilisation and retention of soluble arsenic, cadmium and zinc by biochar. Environ. Pollut. 159:474-80.

Bhattacharyya P, Tripathy S, Kim K, Kim SH, 2008. Arsenic fractions and enzyme activities in arsenic-contaminated soils by groundwater irrigation in West Bengal. Ecotoxicol. Environ. Saf. 71:149-56.

Blagodatskaya E, Kuzyakov Y, 2008. Mechanisms of real and apparent priming effects and their dependence on soil microbial biomass and community structure:critical review. Biol. Fertil. Soils 45:115-31.

Branzini A, Zubillaga MS, 2012. Comparative use of soil organic and inorganic amendments in heavy metals stabilization. Appl. Environ. Soil Sci. 721032.

Buss W, Graham MC, Shepherd JG, Mašek O, 2016. Risks and benefits of marginal biomass-derived biochars for plant growth. Science Total Environ. 569-570:496-506.

Cao X, Ma L, Shiralipour A, 2003. Effects of compost and phosphate amendments on arsenic mobility in soils and arsenic uptake by the hyperaccumulator, Pteris vittata L. Environ. Pollut. 126:157-67.

Castaldi P, Demurtas D, Silvetti M, Deiana S, Garau G, 2017. Interaction of the water soluble fraction of MSW-composts with $\mathrm{Pb}(\mathrm{II})$ and $\mathrm{Cu}(\mathrm{II})$ ions. J. Environ. Manage. 192:39-47.

Castaldi P, Garau G, Deiana P, Melis P, 2009a. Evolution of carbon compounds during municipal solid waste composting: suitabil- 
ity of chemical and biochemical parameters in defining the stability and maturity of the end product. pp. 17-31 in J. MartínGil (Ed.), Compost II. Dynamic soil, dynamic plant 3 (Special Issue 1), Global Science Book.

Castaldi P, Mele E, Silvetti M, Garau G, Deiana S, 2014. Water treatment residues as accumulators of oxoanions in soil. Sorption of arsenate and phosphate anions from an aqueous solution. J. Hazard. Mater. 264:144-52.

Castaldi P, Melis P, Silvetti M, Deiana P, Garau G, 2009b. Influence of pea and wheat growth on $\mathrm{Pb}, \mathrm{Cd}$, and $\mathrm{Zn}$ mobility and soil biological status in a polluted amended soil. Geoderma 151:241-8.

Castaldi P, Santona L, Melis P, 2005. Heavy metals immobilization by chemical amendments in a polluted soil and influence on white lupin growth. Chemosphere 60:365-71.

Castaldi P, Silvetti M, Garau G, Demurtas D, Deiana S, 2015. Copper(II) and lead(II) removal from aqueous solution by water treatment residues. J. Hazard. Mater. 283:240-7.

Castaldi P, Silvetti M, Manzano R, Brundu G, Roggero PP, Garau G, 2018. Mutual effect of Phragmites australis, Arundo donax and immobilization agents on arsenic and trace metals phytostabilization in polluted soils. Geoderma 314:63-72.

Castaldi P, Silvetti M, Enzo S, Deiana S, 2011. X-ray diffraction and thermal analysis of bauxite ore-processing waste (red mud) exchanged with arsenate and phosphate. Clays Clay Miner. 59:189-99.

Clarke CE, Stone W, Hardie AG, Quinton JN, Blake LI, Johnson KL, 2019. Better together: water treatment residual and poorquality compost improves sandy soil fertility. J. Environ. Qual. 48:1781-8.

Conesa HM, Maria-Cervantes A, Alvarez-Rogel J, GonzalezAlcaraz MN, 2014. Role of rhizosphere and soil properties for the phytomanagement of a salt marsh polluted by mining wastes. Int. J. Environ. Sci. Technol. 11:1353-64.

Diacono M, Montemurro F, 2010. Long-term effects of organic amendments on soil fertility. A review. Agron. Sustain. Dev. 30:401-22.

Diquattro S, Garau G, Lauro GP, Silvetti M, Deiana S, Castaldi P, 2018. Municipal solid waste compost as a novel sorbent for antimony $(\mathrm{V})$ : adsorption and release trials at acidic $\mathrm{pH}$. Environ. Sci. Pollut. Res. 25:5603-15.

Ellis RJ, Morgan P, Weightman AJ, Fry JC, 2003. Cultivationdependent and -independent approaches for determining bacterial diversity in heavy-metal-contaminated soil. Appl. Environ. Microbiol. 69:3223-30.

Evans K, 2016. The History, challenges, and new developments in the management and use of bauxite residue. J. Sustain. Met. 2:316-31.

Eykelbosh AJ, Johnson MS, Couto EG, 2015. Biochar decreases dissolved organic carbon but not nitrate leaching in relation to vinasse application in a Brazilian sugarcane soil. J. Environ. Manage. 149:9-16.

Fang S, Tsang DCW, Zhou F, Zhang W, Qiu R, 2016. Stabilization of cationic and anionic metal species in contaminated soils using sludge-derived biochar. Chemosphere 149:263-71.

Fellet G, Marmiroli M, Marchiol L, 2014. Elements uptake by metal accumulator species grown on mine tailings amended with three types of biochar. Sci. Total Environ. 468-469:598608.

Fendorf S, Nico PS, Kocar BD, Masue Y, Tufano KJ, 2010. Arsenic chemistry in soils and sediments. In: B. Singh, M. Grafe (Eds.), Developments in soil science. Elsevier, Amsterdam, The Netherlands, pp. 357-378.
Fiorentino N, Mori M, Cenvinzo V, Duri LG, Gioia L, Visconti D, Fagnano M, 2018. Assisted phytoremediation for restoring soil fertility in contaminated and degraded land. Ital. J. Agron. 13(1S):34-44.

Fitz WJ, Wenzel WW, 2002. Arsenic transformations in the soilrhizosphere-plant system:fundamentals and potential application to phytoremediation. J. Biotechnol. 99:259-278.

Fumagalli P, Comolli R, Ferrè C, Ghiani A, Gentili R, Citterio S, 2014. The rotation of white lupin (Lupinus albus, L.) with metal-accumulating plant crops :A strategy to increase the benefits of soil phytoremediation. J. Environ. Manage. 145:35-42.

Garau G, Reeve WG, Brau L, Deiana P, Yates RJ, James D, Tiwari R, O'Hara G, Howieson JG, 2005. The symbiotic requirements of different Medicago spp. suggest the evolution of Sinorhizobium meliloti and S. medicae with hosts differentially adapted to soil $\mathrm{pH}$. Plant and Soil 176:263-277.

Garau G, Castaldi P, Santona L, Deiana P, Melis P, 2007. Influence of red mud, zeolite and lime on heavy metal immobilization, culturable heterotrophic microbial populations and enzyme activities in a contaminated soil. Geoderma 142:45-57.

Garau G, Porceddu A, Sanna M, Silvetti M, Castaldi P, 2019a. Municipal solid wastes as a resource for environmental recovery:Impact of water treatment residuals and compost on the microbial and biochemical features of As and trace metal-polluted soils. Ecotox. Environ. Safe. 174:445-54.

Garau G, Silvetti M, Castaldi P, Mele E, Deiana P, Deiana S, 2014. Stabilising metal(loid)s in soil with iron and aluminium-based products:microbial, biochemical and plant growth impact. J. Environ. Manage. 139:146-53.

Garau G, Silvetti M, Deiana S, Deiana P, Castaldi P, 2011. Longterm influence of red mud on As mobility and soil physicochemical and microbial parameters in a polluted sub-acidic soil. J. Hazard. Mater. 185:1241-8.

Garau G, Silvetti M, Vasileiadis S, Donner E, Diquattro S, Deiana S, Lombi E, Castaldi P, 2017. Use of municipal solid wastes for chemical and microbiological recovery of soils contaminated with metal(loid)s. Soil Biol. Biochem. 111:25-35.

Garau M, Castaldi P, Patteri G, Roggero PP, Garau G, 2020. Evaluation of Cynara cardunculus L. and municipal solid waste compost for aided phytoremediation of multi potentially toxic element-contaminated soils. Environ. Sci. Pollut. Res. [In press].

Garau M, Garau G, Diquattro S, Roggero PP, Castaldi P, 2019b. Mobility, bioaccessibility and toxicity of potentially toxic elements in a contaminated soil treated with municipal solid waste compost. Ecotox. Environ. Safe. 186:109766.

Glaser B, Lehr VI, 2019. Biochar efects on phosphorus availability in agricultural soils: a meta-analysis. Sci. Rep. 9:9338.

Gómez JD, Denef K, Stewart CE, Zheng J, Cotrufo MF, 2014. Biochar addition rate influences soil microbial abundance and activity in temperate soils. Eur. J. Soil Sci. 65:28-39.

Gorovtsov A, Rajput V, Minkina T, Mandzhieva, S, Sushkova, S, Kornienko, I, Tatiana VG, Chokheli V, Aleshukina I, Zinchenko V, Fedorenko E, Movsesyan H, 2019. The role of biochar-microbe interaction in alleviating heavy metal toxicity in Hordeum vulgare L. grown in highly polluted soils. Appl. Geochem. 104:93-101.

Gupta VK, Sharma S, 2002. Removal of cadmium and zinc from aqueous solutions using red mud. Environ. Sci. Technol. 36:3612-7.

Houben D, Sonnet P, 2015. Impact of biochar and root-induced changes on metal dynamics in the rhizosphere of Agrostis capillaris and Lupinus albus. Chemosphere 139:644-51. 
Hsu W-M, Hseu Z-Y, 2011. Rehabilitation of a sandy soil with aluminium-water treatment residual. Soil Sci. 176:691-8.

Huang M, Zhu Y, Li Z, Huang B, Luo N, Liu C, Zeng G, 2016. Compost as a soil amendment to remediate heavy metal-contaminated agricultural soil: mechanisms, efficacy, problems, and strategies. Water Air Soil Pollut. 227:359.

Ibrahim M, Li G, Khan S, Chi Q, Xu Y, Zhu Y, 2017. Biochars mitigate greenhouse gas emissions and bioaccumulation of potentially toxic elements and arsenic speciation in Phaseolus vulgaris L. Environ Sci. Pollut. Res. 25:15264.

Ippolito JA, Barbarick KA, Elliott HA, 2011. Drinking water treatment residuals: a review of recent uses. J. Environ. Qual. 40:112.

Jiang L, Han G, Lan Y, Liu S, Gao J, Yang X, Meng J, Chen W, 2017. Corn cob biochar increases soil culturable bacterial abundance without enhancing their capacities in utilizing carbon sources in Biolog Eco-plates. J. Integr. Agric. 16:713-24.

Jien S-H, Wang C-S, 2013. Effects of biochar on soil properties and erosion potential in a highly weathered soil. Catena 110:225-33.

Jindo K, Mizumoto H, Sawada Y, Sanchez-Monedero MA, Sonoki T, 2014. Physical and chemical characterization of biochars derived from different agricultural residues. Biogeosciences 11:6613-21.

Kosmulski M, 2016. Isoelectric points and points of zero charge of metal (hydr)oxides:50 years after Parks' review. Adv. Colloid Interface Sci. 238:1-61.

Kouki S, Saidi N, M'hiri F, Hafiane A, 2015. A comparative study of nutrients, cadmium, and chromium bioremoval efficiencies of three emergent macrophytes from a metal-contaminated wastewater. Clean Soil Air Water 43:1531-7.

Kumpiene J, Bert V, Dimitriou I, Eriksson J, Friesl-Hanl W, Galazka R, Herzig R, Janssen J, Kidd P, Mench M, Müller I, Neu S, Oustriere N, Puschenreiter M, Renella G, Roumier PH, Siebielec G, Vangronsveld J, Manier N, 2014. Selecting chemical and ecotoxicological test batteries for risk assessment of trace element-contaminated soils (phyto)managed by gentle remediation options (GRO). Sci. Total Environ. 496:510-22.

Lebrun M, Miard F, Nandillon R, Scippa GS, Bourgerie S, Morabito D, 2019. Biochar effect associated with compost and iron to promote $\mathrm{Pb}$ and $\mathrm{As}$ soil stabilization and Salix viminalis L. growth. Chemosphere 222:810-22.

Lee SH, Kim EY, Park H, Yun J, Kim JG, 2011. In situ stabilization of arsenic and metal-contaminated agricultural soil using industrial by-products. Geoderma 161:1-7.

Li JS, Beiyuan J, Tsang DCW, Wang L, Poon CS, Li,XD, Fendorf S, 2017. Arsenic containing soil from geogenic source in Hong Kong:Leaching characteristics and stabilization/solidification. Chemosphere 182:31-9.

Lin Y, Munroe P, Joseph S, Henderson R, Ziolkowski A, 2012. Water extractable organic carbon in untreated and chemical treated biochars. Chemosphere 87:151-7.

Lombi E, Hamon RE, Wieshammer G, McLaughlin MJ, McGrath SP, 2004. Assessment of the use of industrial by-products to remediate a copper- and arsenic-contaminated soil. J. Environ. Qual. 33:902-10.

Luengo C, Brigante M, Antelo J, Avena M, 2006. Kinetic of phosphate adsorption on goethite: comparing batch adsorption and ATR-IR measuraments. J. Colloid Interface Sci. 300:511-8.

Lyu F, Hu Y, Wang L, Sun W, 2021. Dealkalization processes of bauxite residue: a comprehensive review. J. Hazard. Mater. 403:123671.

Manzano R, Diquattro S, Roggero PP, Pinna MV, Garau G,
Castaldi P, 2020. Addition of softwood biochar to contaminated soils decreases the mobility, leachability and bioaccesibility of potentially toxic elements. Sci. Total Environ. 739:139946.

Manzano R, Silvetti M, Garau G, Deiana S, Castaldi P, 2016. Influence of iron-rich water treatment residues and compost on the mobility of metal(loid)s in mine soils. Geoderma 283:1-9.

Martínez CE, Jacobson AR, McBride MB, 2003. Aging and temperature effects on DOC and elemental release from a metal contaminated soil. Environ. Pollut. 122:135-43.

Mehmood S, Rizwan M, Bashir S, Ditta A, Aziz O, Yong LZ, Dai Z, Akmal M, Ahmed W, Adeel M, Imtiaz M, Tu S, 2018. Comparative effects of biochar, slag and ferrous-Mn ore on lead and cadmium immobilization in soil. Bull. Environ. Contam. Toxicol. 100:286-92.

Mench M, Vangronsveld J, Lepp N, Bleeker P, Ruttens A, Geebelen W, 2006. Phytoremediation of metal-contaminated soils. In: J.L. Morel, et al. (Eds.), Phytoremediation of metalcontaminated soils. Springer, The Netherlands, pp. 109-190.

Miller M, Palojarvi A, Rangger A, Reeslev M, Kjoller A, 1998. The use of fluorogenic substrates to measure fungal presence and activity in soil. Appl. Environ. Microb. 64:613-7.

Mohapatra PK, 2008. Textbook of environmental microbiology. IK International Publishing House Pvt. Ltd, New Delhi, India.

Mombelli D, Barella S, Gruttadauria A, Mapelli C, 2019. Iron recovery from bauxite tailings red mud by thermal reduction with blast furnace sludge. Appl. Sci. 22:4902.

Moreno-Barriga F, Faz Á, Acosta JA, Soriano-Disla M, MartínezMartínez S, Zornoza R, 2017. Use of Piptatherum miliaceum for the phytomanagement of biochar amended Technosols derived from pyritic tailings to enhance soil aggregation and reduce metal(loid) mobility. Geoderma 307:159-71.

Mulligan CN, Yong RN, Gibbs BF, 2001. Remediation technologies for metal contaminated soils and groundwater: an evaluation. Eng. Geol. 60:193-207.

Nagar R, Sarkar D, Punamiya P, Datta R, 2015. Drinking water treatment residual amendment lowers inorganic arsenic bioaccessibility in contaminated soils: a long term study. Water Air. Soil. Pollut. 226:366.

Nejad ZD, Rezania S, Jung MC, Al-Ghamdi AA, Mustafa AEZMA, Elshikh MS, 2021. Effects of fine fractions of soil organic, semi-organic, and inorganic amendments on the mitigation of heavy metal(loid)s leaching and bioavailability in a post-mining area. Chemosphere 271:129538.

Nirel PMV, Morel FMM, 1990. Pitfalls of sequential extractions. Water Res. 24:1055-6.

Novak JM, Ippolito JA, Ducey TF, Watts DW, Spokas KA, Trippe KM, Sigua GC, Johnson MG, 2018. Remediation of an acidic mine spoil: miscanthus biochar and lime amendment affects metal availability, plant growth, and soil enzyme activity. Chemosphere 205:709-18.

Oliveira A, Pampulha ME, 2006. Effects of long-term heavy metal contamination on soil microbial characteristics. J. Biosci. Bioeng. 102:157-61.

Palansooriya KN, Shaheen SM, Chen SS, Tsang DCW, Hashimoto Y, Hou D, Bolan NS, Rinklebe J, Ok YS, 2020. Soil amendments for immobilization of potentially toxic elements in contaminated soils: a critical review. Environ. Int. 134:105046.

Paradelo R, Barral MT, 2012. Evaluation of the potential capacity as biosorbents of two MSW composts with different $\mathrm{Cu}, \mathrm{Pb}$ and $\mathrm{Zn}$ concentrations. Bioresour. Technol. 104:810-3.

Pardo T, Martínez-Fernandez D, de la Fuente C, Clemente R, Komarek M, Bernal MP, 2016. Maghemite nanoparticles and ferrous sulfate for the stimulation of iron plaque formation and 
arsenic immobilization in Phragmites australis. Environ. Pollut. 219:296-304.

Park JH, Lamb D, Paneerselvam P, Choppala G, Bolan N, Chung JW, 2011. Role of organic amendments on enhanced bioremediation of heavy metal(loid) contaminated soils. J. Hazard. Mater. 185:549-74.

Pascual JA, Moreno JL, Hernández T, García C, 2002. Persistence of immobilised and total urease and phosphatase activities in a soil amended with organic wastes. Bioresour. Technol. 82:738.

Pérez-Sirvent C, Hernández-Pérez C, Martínez-Sánchez MJ, García-Lorenzo ML, Bech J, 2017. Metal uptake by wetland plants:implications for phytoremediation and restoration. J. Soils Sediments 17:1384-93.

Phillips IR, 1998. Use of soil amendments to reduce nitrogen, phosphorus and heavy metal availability. J. Soil Contam. 7:191-212.

Qiao J, Liu T, Wang X, Li F, Lv Y, Cui J, Zeng X, Yuan Y, Liu C, 2018. Simultaneous alleviation of cadmium and arsenic accumulation in rice by applying zero-valent iron and biochar to contaminated paddy soils. Chemosphere 195:260-71.

Quintela-Sabarís C, Marchand L, Kidd PS, Friesl-Hanl W, Puschenreiter M, Kumpiene J, Müller I, Neu S, Janssen J, Vangronsveld J, Dimitriou I, Siebielec G, Gałązka R, Bert V, Herzig R, Cundy, A.B, Oustrière N, Kolbas A, Mench M, 2017. Assessing phytotoxicity of trace element-contaminated soils phytomanaged with gentle remediation options at ten European field trials. Sci. Total Environ. 599-600:1388-98.

Rao CRM, Sahuquillo A, Sanchez JL, 2008. A review of the different methods applied in environmental geochemistry for single and sequential extraction of trace elements in soils and related materials. Water Air Soil Pollut. 189: 291-333.

Regulation (EU) 2019/1009 of 5 June 2019. Regulation of the European parliament and of the council laying down rules on the making available on the market of EU fertilising products and amending, Regulations (EC) No 1069/2009 and (EC) No $1107 / 2009$ and repealing Regulation (EC) No 2003/2003. Official Journal of the European Union, L 170, 25 June 2019.

Rocco C, Agrelli D, Tafuro M, Caporale AG, Adamo P, 2018. Assessing the bioavailability of potentially toxic elements in soil: A proposed approach. Ital. J. Agron. 13(1S):16-22.

Sanderson P, Naidu R, Bolan N, 2015. Effectiveness of chemical amendments for stabilisation of lead and antimony in riskbased land management of soils of shooting ranges. Environ. Sci. Pollut. Res. 22:8942-56.

Santona L, Castaldi P, Melis P, 2006. Evaluation of the interaction mechanisms between red muds and heavy metals. J. Hazard. Mater. 136:324-9.

Siedt M, Schäffer A, Smith KEC, Nabel M, Roß-Nickoll M, van Dongen JT, 2021. Comparing straw, compost, and biochar regarding their suitability as agricultural soil amendments to affect soil structure, nutrient leaching, microbial communities, and the fate of pesticides. Sci. Total Environ. 751:141607.

Sigurdarson JJ, Svane S, Karring H, 2018. The molecular processes of urea hydrolysis in relation to ammonia emissions from agriculture. Rev. Environ. Sci. Bio-Technol. 17:241-58.

Silvetti M, Castaldi P, Holm PE, Deiana S, Lombi E, 2014. Leachability, bioaccessibility and plant availability of trace elements in contaminated soils treated with industrial by-products and subjected to oxidative/reductive conditions. Geoderma 214-215:204-12.

Silvetti M, Demurtas D, Garau G, Deiana S, Castaldi P, 2017. Sorption of $\mathrm{Pb}, \mathrm{Cu}, \mathrm{Cd}$, and $\mathrm{Zn}$ by municipal solid waste com- posts:metal retention and desorption mechanisms. Clean-Soil Air Water 45:1600253.

Speir TW, Kettles HA, Parshotam A, Searle PL, Vlaar LNC, 1999. Simple kinetic approach to determine the toxicity of As[V] to soil biological properties, Soil Biol. Biochem. 31:705-13.

Strickland MS, Rousk J, 2010. Considering fungal:bacterial dominance in soils - methods, controls, and ecosystem implications. Soil. Biol. Biochem. 42:1385-95.

Summer RN, Smirk DD, Karafilis D, 1996. Phosphorus retention and leachates from sandy soil amended with bauxite residue (red mud). Austr. J. Soil Res. 34:555-67.

Sundman A, Karlsson T, Persson P, 2015. Reactivity of Fe from a natural stream water towards As(V). Appl. Geochem 61:18591.

Tan D, Long J, Li B, Ding D, Du H, Lei M, 2018. Fraction and mobility of antimony and arsenic in three polluted soils: a comparison of single extraction and sequential extraction. Chemosphere 213:533-40.

Tandy S, Healey JR, Nason MA, Williamson JC, Jones DL, 2009. Remediation ofmetal polluted mine soil with compost:co-composting versus incorporation. Environ. Pollut 157:690-7.

Tandy S, Meier N, Schulin R, 2017. Use of soil amendments to immobilize antimony and lead in moderately contaminated shooting range soils. J. Hazard. Mater. 324:617-25.

Taneez M, Hurel C, 2019. A review on the potential uses of red mud as amendment for pollution control in environmental media. Environ. Sci. Pollut. Res. 26:22106-25.

Tessier A, Campbell PGC, Bisson M, 1979. Sequential extraction procedure for the speciation of particulate trace metals. Anal. Chem. 51:844-51.

Timms-Wilson TM, Griffiths RI, Whiteley AS, Prosser JI, Bailey MJ, 2006. Detection of active bacterial populations in soil. In: J.D. van Elsas, J.K. Jansson, J.T. Trevors (Eds.), Modern soil microbiology - second edition. CRC Press, Boca Raton, FL, USA, pp. 387-407.

Udovic M, McBride MB, 2012. Influence of compost addition on lead and arsenic bioavailability in reclaimed orchard soil assessed using Porcellio scaber bioaccumulation test. J. Hazard. Mater. 205-206:144-9.

van Elsas JD, Torsvik V, Hartmann A, Øvreås L, Jansson JK, 2006. The bacteria and archaea in soil. In: J.D. van Elsas, J.K. Jansson, J.T. Trevors (Eds.), Modern soil microbiology - second edition. CRC Press, Boca Raton, FL, USA, pp. 83-105.

Van Vleek B, Amarasiriwardena D, Xing B, 2011. Investigation of distribution of soil antimony using sequential extraction and antimony complexed to soil-derived humic acids molar mass fractions extracted from various depths in a shooting range soil. Microchem. J. 97:68-73.

Ventorino V, Faraco V, Romano I, Pepe O, 2018. Responses of bacterial community structure and diversity to soil eco-friendly bioremediation treatments of two multi-contaminated fields. Ital. J. Agron. 13(1S):53-8.

Visconti D, Fiorentino N, Stinca A, Di Mola I, Fagnano M, 2018. Use of the native vascular flora for risk assessment and management of an industrial contaminated soil. Ital. J. Agron. 13(1S):23-33.

Wang S, Mulligan CN, 2009. Enhanced mobilization of arsenic and heavy metals from mine tailings by humic acid. Chemosphere 74:274-9.

Wenzel WW, Kirchbaumera N, Prohaskab T, Stingeder G, Lombi E, Adriano DC, 2001. Arsenic fractionation in soils using an improved sequential extraction procedure. Anal. Chim. Acta 436:309-23. 
Wong MH, 2003. Ecological restoration of mine degraded soils, with emphasis on metal contaminated soils. Chemosphere 50:775-80.

Xu X, Cao X, Zhao L, Wang H, Yu H, Gao B, 2013. Removal of $\mathrm{Cu}, \mathrm{Zn}$, and $\mathrm{Cd}$ from aqueous solutions by the dairy manurederived biochar. Environ. Sci. Pollut. Res. 20:358-68.

Xu X, Zhao Y, Sima J, Zhao L, Masek O, Cao X, 2017. Indispensable role of biocharinherent mineral constituents in its environmental applications:a review. Bioresour. Technol. 241:887-99.

Yang SX, Liao B, Yang ZH, Chai LY, Li JT, 2016. Revegetation of extremely acid mine soils based on aided phytostabilization:a case study from southern China. Sci. Total Environ. 562:42734.

Yousaf B, Liu G, Abbas Q, Ullah H, Wang R, Zia-ur-Rehman M, Amina, Niu Z, 2018. Comparative effects of biocharnanosheets and conventional organic-amendments on health risks abatement of potentially toxic elements via consumption of wheat grown on industrially contaminated-soil. Chemosphere 192:161-70.

Zhang H, Shao J, Zhang S, Zhang X, Chen H, 2020. Effect of phosphorus-modified biochars on immobilization of $\mathrm{Cu}$ (II), Cd (II), and As (V) in paddy soil. J. Hazard. Mater. 390:121349.
Zhang WH, Mao SY, Chen H, Huang L, Qiu RL, 2013. Pb(II) and Cr(VI) sorption by biochars pyrolyzed from the municipal wastewater sludge under different heating conditions. Bioresour. Tecnol. 147:545-52.

Zhang X, Zhang X, Huang K, 2016. Phytostabilization of acidic soils with heavy metal contamination using three forage grasses in combination with organic and inorganic amendments. Soil Sediment Contam. 25:459-75.

Zhao B, O'Connor D, Shen Z, Tsang DCW, Rinklebe J, Hou D, 2020. Sulfur-modified biochar as a soil amendment to stabilize mercury pollution: an accelerated simulation of long-term aging effects. Environ. Pollut. 264:114687.

Zhao Y, Liu R, Awe OW, Yang Y, Shen C, 2018. Acceptability of land application of alum-based water treatment residuals - An explicit and comprehensive review. Chem. Eng. J. 353:717-26.

Zhao Y, Pei Y, Xiang R, Cheng Y, 2016. Effects of drinking water treatment residuals on the quality of different soils from southern and northern agricultural regions. Res. Environ. Sci. 29:1497-505.

Zornoza, P, Vàzquez, S, Esteban, E, Fernàndez-Pascual, M, Carpena, R, 2002. Cadmium-stress in nodulated white lupin:strategies to avoid toxicity. Plant Physiol. Biochem. 40:1003-9. 